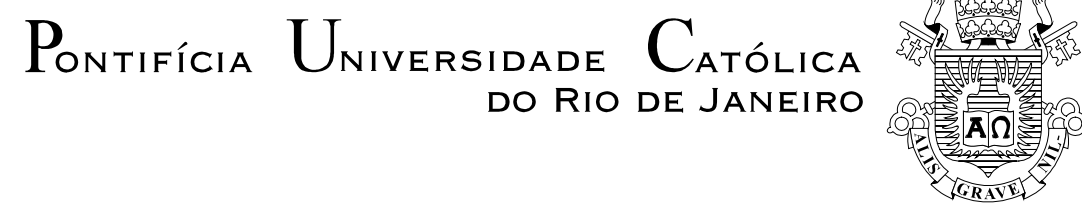

NAYARA MARFIM GILABERTE BEZERRA

\title{
Uma cartografia dos restos
}

Tese apresentada como requisito parcial para obtenção do grau de Doutor pelo Programa de Pós-Graduação em Literatura, Cultura e Contemporaneidade da PUC-Rio.

Orientadora: Profa. Marília Rothier Cardoso

Rio de Janeiro

Setembro de 2019 
Pontifícia Universidade C Católica DO RIO DE JANEIRO

\section{NAYARA MARFIM GILABERTE BEZERRA}

\section{Uma cartografia dos restos}

Tese apresentada como requisito parcial para obtenção do grau de Doutor pelo Programa de Pós-Graduação em Literatura, Cultura e Contemporaneidade da PUC-Rio. Aprovada pela Comissão Examinadora abaixo.

Profa. Marília Rothier Cardoso

Orientadora

Departamento de Letras - PUC-Rio

Profa. Rosana Kohl Bines

Departamento de Letras - PUC-Rio

Profa. Claudia Fernanda Chigres

Departamento de Letras - PUC-Rio

Profa. Ana Cristina de Rezende Chiara

UERJ

Prof. Italo Moriconi Junior

UERJ

Rio de Janeiro, 16 de setembro de 2019. 
Todos os direitos reservados. É proibida a reprodução total ou parcial do trabalho sem a autorização da universidade, da autora e do orientador.

\section{Nayara Marfim Gilaberte Bezerra}

Bacharel em Psicologia pela Universidade Federal do Rio de Janeiro. Especialista em Literatura Brasileira pela Universidade do Estado do Rio de Janeiro. Mestre em Literatura, Cultura e Contemporaneidade pela PUCRio, com a dissertação Escritores em cena: a construção midiática do autor na atualidade.

Ficha Catalográfica

Bezerra, Nayara Marfim Gilaberte

Uma cartografia dos restos / Nayara Marfim Gilaberte Bezerra ; orientadora: Marília Rothier Cardoso. - 2019.

$87 \mathrm{f}$. : il. color. ; $30 \mathrm{~cm}$

Tese (doutorado)-Pontifícia Universidade Católica do Rio de Janeiro, Departamento de Letras, 2019.

Inclui bibliografia

1. Letras - Teses. 2. Catar. 3. Resto. 4. Resistência. 5. Lixo. 6.Memória. I. Cardoso, Marília Rothier. II. Pontifícia Universidade Católica do Rio de Janeiro. Departamento de Letras. III. Título. 
Para minha filha Julia,

e para a querida Marília. 


\section{Agradecimentos}

Agradeço, em primeiro lugar e em cada linha deste texto, à minha orientadora Marília Cardoso Rothier.

Quando comecei a pensar nesta tese, há 4 anos e meio, tudo estava muito diferente: eu, minha vida, meu objeto de pesquisa, a forma como eu lidava com as palavras. Este texto mudou muitas vezes e Marília abraçou todas as mudanças, acolhendo silêncios e pausas, respeitando nascimentos e mortes, provocando revoluções no pensamento e na escrita. Sua leitura atenta, generosidade desmedida e brilhantismo intelectual são inspirações de vida. Marília, mestra querida, que sorte a minha ter você por perto.

Agradeço com a voz também embargada à Professora Rosana Kohl Bines pelas aulas instigantes, pela participação na banca de qualificação e por estar de novo dedicando seu olhar sensível e arguto a este trabalho. Em março de 2016, em um seminário de elaboração de projetos, você solicitou que criássemos um diagrama de nossa pesquisa para apresentar à turma. Foi a primeira vez que tudo ruiu. Obrigada. Há muito das suas provocações no meu texto.

Agradeço às Professoras Ana Chiara e Claudia Chigres e ao Professor Ítalo Moriconi pela gentileza de aceitarem compor esta banca de defesa, e à Professora Leila Danziger pela participação na banca de qualificação.

Agradeço também às mulheres da minha vida, minha filha Julia, minha irmã Luana, minha mãe Mônica e as amigas de longa data: Maria, Clarice, Maíra, Luisa, Carol e Raquel. À Julia, tanto tanto. À Luana, meu amor. À minha mãe, Mônica, um pouco de tudo: a vida, o apoio, a diferença, o meu primeiro olhar admirado para uma mulher. À Clarice, por nossa vida há tanto tempo compartida, claro, mas aqui especialmente por ficar ao lado, abrindo passagens para que eu conseguisse receber sua leitura amorosa, sagaz e interessada. À Maria, Maíra, Luisa, Carol e Raquel, um milhão de vezes, obrigada obrigada obrigada por trazerem outros ares para esta vida de escrita. 
E ainda:

À Glória, pela escuta.

À Fernanda, pela envergadura do olhar.

Ao meu irmão, João, pelas melhores e mais escatológicas memórias da infância.

Ao meu pai, Marcos, pelas desde sempre doses generosas de afeto e parceria.

Ao Diogo, companheiro de fazimentos nos anos em que se passaram essa escrita, pelas dores e delícias de viver e gerar uma vida juntos enquanto se tece uma tese.

E, por fim, mas não menos importante: à Universidade Federal do Rio de Janeiro e à Universidade do Estado do Rio de Janeiro, universidades públicas, gratuitas e de indiscutível qualidade, onde pude dar meus primeiros passos acadêmicos, e à PUC-Rio, especialmente ao Departamento de Letras, pela excelência no ensino e abertura potente para novos cenários e modos de escrita. $\mathrm{E}$, claro, à CAPES e à FAPERJ, pelos importantes auxílios concedidos, sem os quais este trabalho (e tantos outros) definitivamente não poderia (não poderão) ter sido (ser) realizado(s).

O presente trabalho foi realizado com apoio da Coordenação de Aperfeiçoamento de Pessoal de Nível Superior (CAPES) - Código de financiamento 001. 


\section{Resumo}

Bezerra, Nayara Marfim Gilaberte; Cardoso, Marília Rothier. Uma cartografia dos restos. Rio de Janeiro, 2019. 87p. Tese de doutorado Departamento de Letras. Pontifícia Universidade Católica do Rio de Janeiro

Esta tese, como um exercício crítico de leitura e escrita, gira em torno da noção de resto e de outras palavras que com ela se relacionam, partindo das figuras do catador e do trapeiro para refletir sobre o processo criativo como ato que aproxima artistas e pesquisadores daqueles que trabalham com o que é descartado, rejeitado e esquecido. Para tanto, apresento uma coleção de fragmentos que versam sobre o gesto de catar a partir da obra da escritora Carolina Maria de Jesus, derivando incialmente do seu conhecido Quarto de despejo para debruçar-me sobre o livro Diário de Bitita. A ênfase na obra em questão, na qual a autora narra cenas de sua infância, parte do mote benjaminiano de acolhimento das sobras e restos das narrativas oficiais, para que, tal como as crianças, possamos fazer história através do lixo da história. $O$ lugar da infância que o Diário nos convida a visitar aproxima ainda a atividade de catadora dos devires criança e trapeira e motiva o diálogo com outros artistas e teóricos para uma conversa sobre resto e resistência, literatura e excremento, lixo e memória. Entre um e outro texto, como respiros, fragmentos inventados ao longo do caminhar da pesquisa são também costurados ao trabalho. Esses textos variam em forma e conteúdo e apresentam lampejos de memória, notas sobre o processo de pesquisa, atravessamentos do momento político que estamos vivendo e invenções biográficas. Compondo um modo crítico-ficcional de pensar a criação artística pela recolha de objetos, memórias e pensamentos, esse movimento pretende, por fim, interrogar-se também sobre o próprio fazer acadêmico, expandindo as noções de catação e coleção para um movimento de observar, escolher e recolher constitutivo do processo de pesquisa.

\section{Palavras Chave}

Catar; resto; resistência; lixo; memória 


\section{Résumé}

Bezerra, Nayara Marfim Gilaberte; Cardoso, Marília Rothier (Directrice). Une cartographie des débris. Rio de Janeiro, 2019. 87p. Tese de doutorado - Departamento de Letras. Pontifícia Universidade Católica do Rio de Janeiro

Cette thèse, comme un exercice critique de lecture et écriture, porte sur la notion de débris et d'autres mots dérivés, partant de la figure du ramasseur de déchets et du chiffonier afin de réflechir sur le processus créatif comme un acte qui rapproche les artistes et les chercheurs de ceux qui travaillent avec ce qui est laissé de côté, rejeté et oublié. Pour cela, je présente une collection de fragments qui abordent le geste de ramasser les déchets à partir de l'oeuvre de l'écrivain Carolina Maria de Jesus, dérivés initialement de son célèbre $<<$ Le dépotoir $>>$ (Quarto de despejo) pour me pencher ensuite sur le livre $<<$ Journal de Bitita >> (Diário de Bitita). L'emphase dans l'oeuvre en question, où l'auteur raconte des scènes de son enfance, a comme déclencheur benjaminien la réception de débris des récits officiels afin que, comme les enfants, on puisse faire histoire en se servant des déchets de l'histoire. La place de l'enfance que le Journal nous présente lie l'activité de ramasseur avec le devenir des enfants chiffoniers et encourage le dialogue avec d'autres artistes et théoriciens pour une conversation sur débris et résistence, littérature et excrément, déchets et mémoire. Entre un texte et l'autre, comme des pauses, des fragments créés au long du parcours de la recherche sont aussi associés au travail. Ces textes varient en forme et contenu et présentent des bribes de mémoire, des notes sur le travail de recherche, croisements du moment politique que l'on vit et des inventions biographiques. Suivant un modèle critique-fictionnel de penser la création artistique par le ramassage d'objets, mémoires et pensées, ce mouvement a pour but de s'interroger aussi sur le faire académique, menant les notions de ramassage de déchets et de collecte vers un mouvement consistant à observer, sélectionner et ramasser constitutif du travail de recherche.

\section{Mots-clés}

Chiffonier; debris; résistence; déchets; mémoire. 


\section{Sumário}

$\begin{array}{ll}\text { 1. Apresentação } & 14\end{array}$

2. 2016, dezembro, primeira história 15

$\begin{array}{ll}\text { 3. O endereço de Deus } & 17\end{array}$

4. A escrita, ela mesma, lixo 19

5. Compor o mapa 20

6. Catar, escolher e recolher 22

7. Recolher dentre outras coisas ou um por um 24

8. Diga-se de passagem 27

9. Porque depois pode ficar bonito, uê 29

10. Comer a felicidade com os pés sujos de areia 31

11. Lançar essa força para o mundo 33

12. Devir-criança, devir-trapeira 35

13. Um modo trapeiro de produção de pensamento 36

14. Instalação literária, cartografia do caos 38

15. A escrita-trapeira de Carolina de Jesus 40

16. Ler com outros sentidos, ruído 42 
18. Como excrever uma tese?

19. Manchas na pele, linguagem

20. Bolsa de cacarecos

21. Coletar para lembrar

53

22. Entre o excesso e a falta

23. Outras histórias

60

24. O começo do mundo

25. A morte da avó

64

26. Percurso, ou notas sobre o processo de pesquisa

66

27. A escrita fragmentária

28. Pobreza de experiência

77

29. Por fim, organizar o pessimismo

82

30. Referências bibliográficas 


\section{Lista de figuras}

Figura 1 - Frame do filme Os catadores e eu, de Agnès Varda

Figura 2 - Favela da Rocinha, foto de Roberto Moreyra

Figura 3: A menina e o ditador, foto de Guinaldo Nicolaevsky

Figura 4 - Bolsa de cacarecos, arquivo pessoal

52

Figura 5 - Varal de Lembranças, de Lygia Segala e Tania Silva

Figura 6 - Frame do filme Os catadores e eu, de Agnès Varda 


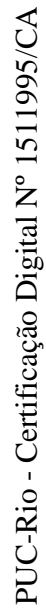

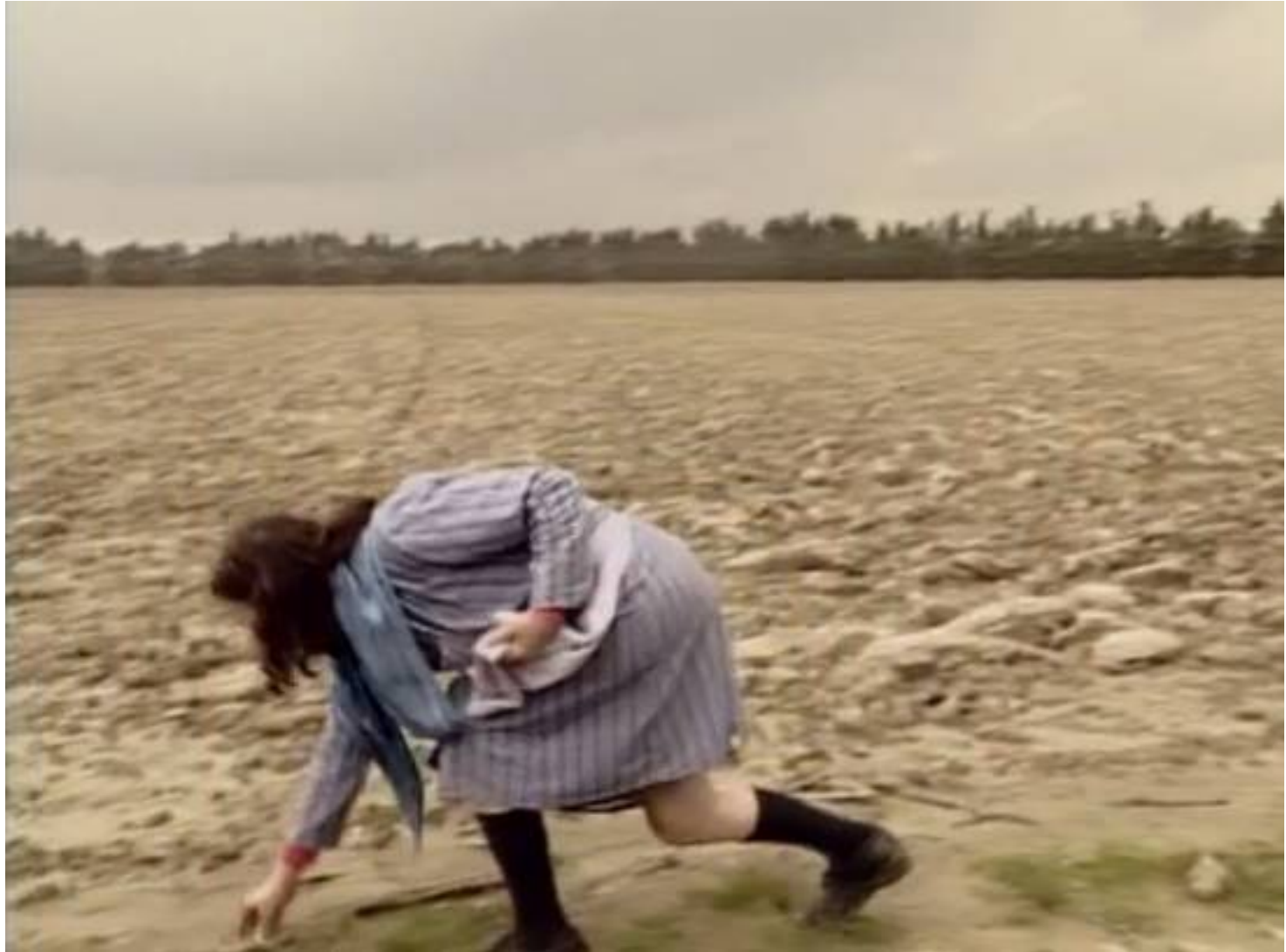

Figura 1: Frame de Os catadores e eu (Agnès Varda, 2000) 
Descobre-se, então, o sentido em que os artistas contemporâneos são "sábios" ou precursores de um gênero especial: recolhem pedaços dispersos do mundo como o faria uma criança ou um trapeiro - Walter Benjamin comparava estas duas figuras com o autêntico sábio materialista. Fazem com que se encontrem coisas fora das classificações habituais, retiram dessas afinidades um gênero de conhecimento novo, que nos abre os olhos sobre aspectos inadvertidos do mundo, sobre o inconsciente mesmo de nossa visão.

[Didi-Huberman]

O mapa é aberto, é conectável em todas as suas dimensões, desmontável, reversível, suscetível de receber modificações constantemente. Ele pode ser rasgado, revertido, adaptar-se a montagens de qualquer natureza, ser preparado por um indivíduo, um grupo, uma formação social. Pode-se desenhá-lo numa parede, concebê-lo como obra de arte, construí-lo como uma ação política ou como uma meditação. (...) Um mapa é uma questão de performance.

[Deleuze e Guatarri] 
1.

\section{Apresentação}

Escrevo em fragmentos para compor um mapa aberto. Essa é a aposta deste trabalho. Operar uma colagem de textos que caminham lado a lado, justapondoos por afinidades não necessariamente complementares ou explicativas. $\mathrm{Na}$ escrita acadêmica muitas vezes uma ideia puxa outra e vão se desfazendo os novelos a caminhar para um objetivo maior. Aqui não há linha de chegada e muitos são os pontos de partida. O gesto de catar conduz esta pesquisa: uma palavra cai lentamente da página do livro e ao me abaixar para recolhê-la tropeço em outra que vem enganchada de um jeito que já não vejo mais o que estava antes na minha mão senão por esse aglomerado de ideias que olha de volta para mim. Não as quero desembaralhar, a atenção da pesquisa por vezes me cansa: por que castigar os textos com o esmiuçar à lupa de especialista?

Encontro na fragmentação um lugar onde o texto respira. Esta tese é feita com as autoras e autores que leio, sem prejuízo de gênero ou hierarquia intelectual. Romance, diário, teatro, poesia, cinema, teoria consagrada e colegas em pleno voo. Nada é nunca original. O suportar movimentos fragmentários (ser suporte de) aparece como aposta em uma possível polifonia não hermenêutica para o texto. Fragmentos coexistem de forma solitária, não precisam compor uma totalidade, podem ser partes relacionáveis, ou não. Enquanto as ligações conduzem o pensamento pela mão, a escrita fragmentária pode se apresentar como ato, como aposta no regime do significante que, no lugar de oferecer significados pela tranquilidade do elo narrativo, deixa em aberto o espaço que convoca o leitor para a cena da leitura. Assim, eu te convido a preencher lacunas, pensar comigo enredos para espaços em branco, construir argumentos que unam um e outro trecho. Ou não. As coisas da vida são mesmo caóticas, então por que não tirar partido dessa tensão? 
2.

\section{6, dezembro, primeira história}

Primeira semana de dezembro. Casa em obras, dois textos do doutorado para escrever, 37 semanas de gravidez e uma vida nova para criar. Há 9 meses, gerar tornou-se imperativo. E tenho pensado nisso de viver a construção de uma identidade de mãe justamente nesse ano em que as questões ligadas ao 'tornarse mulher' estiveram novamente tão presentes no mundo e em mim. E me peguei pensando também que fazer uma filha era na mesma medida um gesto de continuidade e ruptura ${ }^{1}$.

É que sou uma das seis netas geradas pelas três filhas que a minha avó fez. E tudo por aqui começa nela. Minha avó, uma nordestina nascida no começo do século se apaixonou por um caixeiro viajante que conheceu quando ele estava de passagem pela sua cidade natal. Dessa história, surgiram três filhas, uma delas a minha mãe.

Minha árvore genealógica materna sempre começou com uma avó que por algum motivo fugiu da sua cidade para o Rio de Janeiro. Uma mulher do interior do Ceará que, quando tudo era ainda pior para as mulheres de todos os lugares, criou sozinha as três filhas que fez com o.

Meu avô foi sempre um ponto final. As filhas da minha avó nunca puderam falar dele. A gente não podia falar dele. Mas o silêncio fazia barulho e eu ouvia. E lembro de no banco de trás do carro ouvir muitas vezes minha mãe catando pedaços dessa história com as irmãs. O dia em que ele apareceu no aniversário de alguma delas. O dia em que ele apareceu do nada e a minha avó tinha feito uma comida gostosa como se soubesse que ele vinha. O dia em que ele nunca

\footnotetext{
${ }^{1}$ Faço com o que mal conheço do meu corpo uma criança: não é só a minha filha que está sendo gerada cá dentro em carne e osso, nem só o que a partir dessa experiência com ela começo a fabular da minha infância. É uma força que me invade e não é eu, mas cosmos, explosão de mundo: uma infância que não é a minha, que não é uma recordação, mas um bloco, um fragmento anônimo infinito, um devir sempre contemporâneo". (DELEUZE, 1997, p. 129) Nosso devir-criança.
}

*Em toda a tese as citações curtas incorporadas ao texto serão destacadas em itálico. 
mais voltou. Minha avó, quando a gente não resistia e acabava perguntando, ficava nervosa, ralhava com os netos, aquilo não era assunto pra criança, aquilo não era assunto praquela hora, aquilo não era assunto.

Dona Maria era uma mulher evangélica. Eu e minha prima costumávamos passar o final de semana na casa dela e com certa frequência a casa dela era sede de encontros do grupo de oração da igreja. Às vezes eles falavam em línguas. Era um transe eufórico com todos os adultos falando coisas que a gente não entendia e que davam um misto de medo e festa.

Um pouco depois descobri que a igreja ensinou outras línguas para minha avó não falar na dela. E um tanto mais velha perguntei se ela prometia contar a história do meu avô ao menos antes de morrer.

O último dia das mães que passei com a minha avó foi o último dia em que a vi viva. Era o ano de 2012. Lembro que depois do almoço surgiu um álbum de fotos e de dentro do álbum surgiu o meu avô. Eu e minha prima começamos a conversar e a perguntar e a falar sobre o meu avô e a minha avó começou a conversar e a responder e a falar sobre o meu avô. Não lembro dos pormenores da história. Mas tinha homem casado, vergonha, família que reprimia, igreja que reprimia, cidade do interior que reprimia, mudança para o Rio de Janeiro, amor, solidão e mais vergonha.

Três meses depois minha avó morreu. Nunca vou saber se ela contou a história porque ia morrer ou se morreu porque contou a história. 
3.

\section{O endereço de Deus}

A senhora pode me dar o endereço de Deus? Indaga a menina Carolina de Jesus na passagem do Diário de Bitita ${ }^{2}$ que recebe o título de "A cidade" e conta suas desventuras enquanto ainda engatinhante no conhecimento das coisas do mundo. O pedido aparece como vontade de lançar ao céu a provocação: se Deus não gosta de nós, por que é que nos fez nascer? (JESUS, 2014, p. 95)

É tomada pela voz curiosa da infância que Carolina escreve o livro de memórias Diário de Bitita. Organizada em temáticas, a obra foi publicada postumamente na França em 1982, tendo chegado ao Brasil somente quatro anos depois em edição bastante tímida para aquela que havia se tornado uma figura conhecida em todo o mundo, após ter sido "descoberta" pelo repórter Audálio Dantas e ter lançado, em 1960, o livro Quarto de despejo: diário de uma favelada (1976).

Carolina Maria de Jesus nasceu no interior de Minas Gerais, na cidade de Sacramento. Quando tinha sete anos de idade, recebeu o financiamento da esposa do fazendeiro para quem sua mãe trabalhava como empregada doméstica e começou a frequentar uma escola espírita da região. Sua passagem pelo ambiente escolar durou pouco, mas foi tempo suficiente para que aprendesse a ler e escrever, dando continuidade a seu processo educacional por conta própria. Já adulta, mudou-se para São Paulo em 1937 onde inicialmente repetiu o destino da mãe trabalhando como empregada doméstica, até que, cansada da vida que levava nessa profissão e buscando uma atividade que lhe conferisse mais autonomia, tornou-se catadora de papel, atividade que desenvolvia para garantir seu sustento enquanto podia se dedicar à escrita de seus conhecidos diários e nem tão conhecidos contos, poemas e romances. Enquanto catava papéis e o que mais aparecesse para vender, a escritora virava

\footnotetext{
${ }^{2}$ O título Diário de Bitita é uma tradução literal da versão francesa Journal de Bitita. Embora os manuscritos de Carolina de Jesus entregues à Réginet Valbert, jornalista francesa responsável pela primeira publicação do Diário, apontem para o desejo de Carolina de chamar a obra de "Um Brasil para os brasileiros", a opção por intitulá-la Diário foi, segundo estudos e pesquisas, uma estratégia editorial de vincular sua última publicação aos seus dois diários publicados em vida. Para mais informações sobre o processo de edição, consultar o artigo "Vários 'Prólogos' para um Journal de Bitita / Diário de Bitita ou Por que editar Carolina?". (FERNANDEZ, 2014)
} 
sua vida futura do avesso, retirando do lixo os cadernos descartados onde iria compor os manuscritos de sua vasta produção artística.

Quarto de despejo reúne registros do cotidiano da favela do Canindé intercalados por comentários da política vigente e relatos da difícil condição de vida da sua autora. Logo que publicada, a obra teve enorme sucesso e Carolina rapidamente viu-se tomada como símbolo da luta contra as injustiças de uma sociedade que pela primeira vez tinha a seu alcance um livro em que a história de um espaço periférico era contada por um de seus habitantes. A um só tempo mulher negra e pobre, migrante e mãe solteira, a catadora que escrevia para vencer na vida, de um dia para o outro, viu ser possível jogar sua crítica na cara do mundo: (...) eu classifico São Paulo assim: O Palácio é a sala de visita. A prefeitura é a sala de jantar e a cidade é o jardim. E a favela é o quintal onde jogam os lixos. (JESUS, 1976, p. 30) 
4.

A escrita, ela mesma, lixo

No ensaio "La poubelle agréée", do livro O caminho de San Giovanni (2000), coleção de narrativas que transitam entre a escrita memorialista e o texto ensaístico, Ítalo Calvino parte da descrição do seu gesto diário de levar o lixo doméstico para fora de casa e desencadeia uma série de considerações sobre consumo e descarte, apropriação e expropriação, alteridade e subalternidade, tecendo uma crítica à sociedade europeia e seus papéis sociais desiguais e cristalizados, ao mesmo tempo em que se utiliza de sua lixeira como impulso metafórico para propor um pensamento acerca do trabalho do escritor. Estes meus pensamentos que vocês leem são o que se salvou de dezenas de folhas amassadas no cesto (CALVINO, 2000, p. 87), insinua o autor ao nos contar que dentre os muitos lixos produzidos pelo homem, mais the interessa o resto da escrita. No entanto, destaco: indo além da possibilidade de entender o resto da escrita como rascunho, rasura, aquilo que do processo criativo jogamos fora, Calvino propõe ser a escrita, ela mesma, lixo: aquilo que é expelido, expulso do corpo do autor - tal como a secreção, a ejaculação e o excremento. Para ele, a escrita, o lixo e a excreção compartilham, portanto, o mesmo lugar recluso, indesejável, alheio aos homens. São sempre sobras, resíduos, fragmentos, ou seja, pedaços de corpus eliminados. (FERRAZ, 2015, p.102)

Carolina retira o lixo do campo metafórico, escreve com ele: construía suas obras em cadernos usados, folhas gastas e blocos de papel catados do chão e das lixeiras que revirava como profissão.

\footnotetext{
O pensamento de Carolina Maria de Jesus comunica-se à mão que escreve por assaltos. Sua frase sincopada retraça o caminho, o método, daquela que se abaixa a cada passo para retirar do monturo do lixo algo produtivo, o corpo escreve, está inscrito nas páginas onde a letra de Carolina se sobrepõe a outras letras com as quais disputa espaço é a luta da negra para se tornar escritora. (CHIARA, 2008, p.2)
} 
5.

\section{Compor o mapa}

Operar a construção desta tese por uma coleção de fragmentos foi tarefa em que mergulhei ao me deparar, tantas e quantas vezes, com a ideia de cartografia. A partir dela, a decisão: adotar o fragmentário como estratégia, ler o precário como sintoma, desenvolver a pesquisa como processo e a escrita como mapeamento de múltiplas possibilidades.

A guinada pós-estruturalista das décadas de 60 e 70 trouxe para a geografia um novo entendimento sobre a natureza dos mapas e seus princípios de representação. Superando seu emprego como a ciência da representação gráfica de uma realidade estática no papel, os cartógrafos da atualidade enfrentam o desafio de estudar a natureza performativa e dinâmica dos mapas. Nessa perspectiva, a cartografia passa a ser entendida como uma atividade que procura apresentar situações, espaços e práticas humanas que se encontram em um processo contínuo de criação.

Com Gilles Deleuze e Félix Guattari (1995), a cartografia, mais do que adquirir o estatuto de método, torna-se um modo de pensamento que se desdobra sobre as coisas do mundo e cria seus próprios movimentos e desvios. Assim, no lugar de representar objetos, constrói um mapa do presente que apresenta conjuntos de fragmentos, em eterno movimento de produção. A partir deles, o sentido da cartografia é de acompanhamento de processos, conexões de rede ou rizomas:

\footnotetext{
Diferente é o rizoma, mapa e não decalque. Fazer o mapa, não o decalque. A orquídea não reproduz o decalque da vespa, ela compõe um mapa com a vespa no seio de um rizoma. Se o mapa se opõe ao decalque é por estar inteiramente voltado para uma experimentação ancorada no real. (DELEUZE; GUATTARI, 1995, p. 22)
}

Nos estudos da biologia sobre o reino vegetal, rizoma é a definição dada para um tipo de caule que cresce horizontalmente, geralmente embaixo da terra, mas que pode ter também porções aéreas. Em oposição à árvore com suas raízes, 
dizem Deleuze e Guatarri na transmutação deste conceito da botânica para o campo dos estudos filosóficos, o rizoma não começa e nem conclui, não encarna a ideia de filiação, é aliança, encontra-se sempre no meio, [tendo] como tecido a conjunção "e... e... e..." Há nesta conjunção força suficiente para sacudir e desenraizar o verbo ser: para onde vai você? De onde você vem? Aonde quer chegar? São questões inúteis. (p. 37)

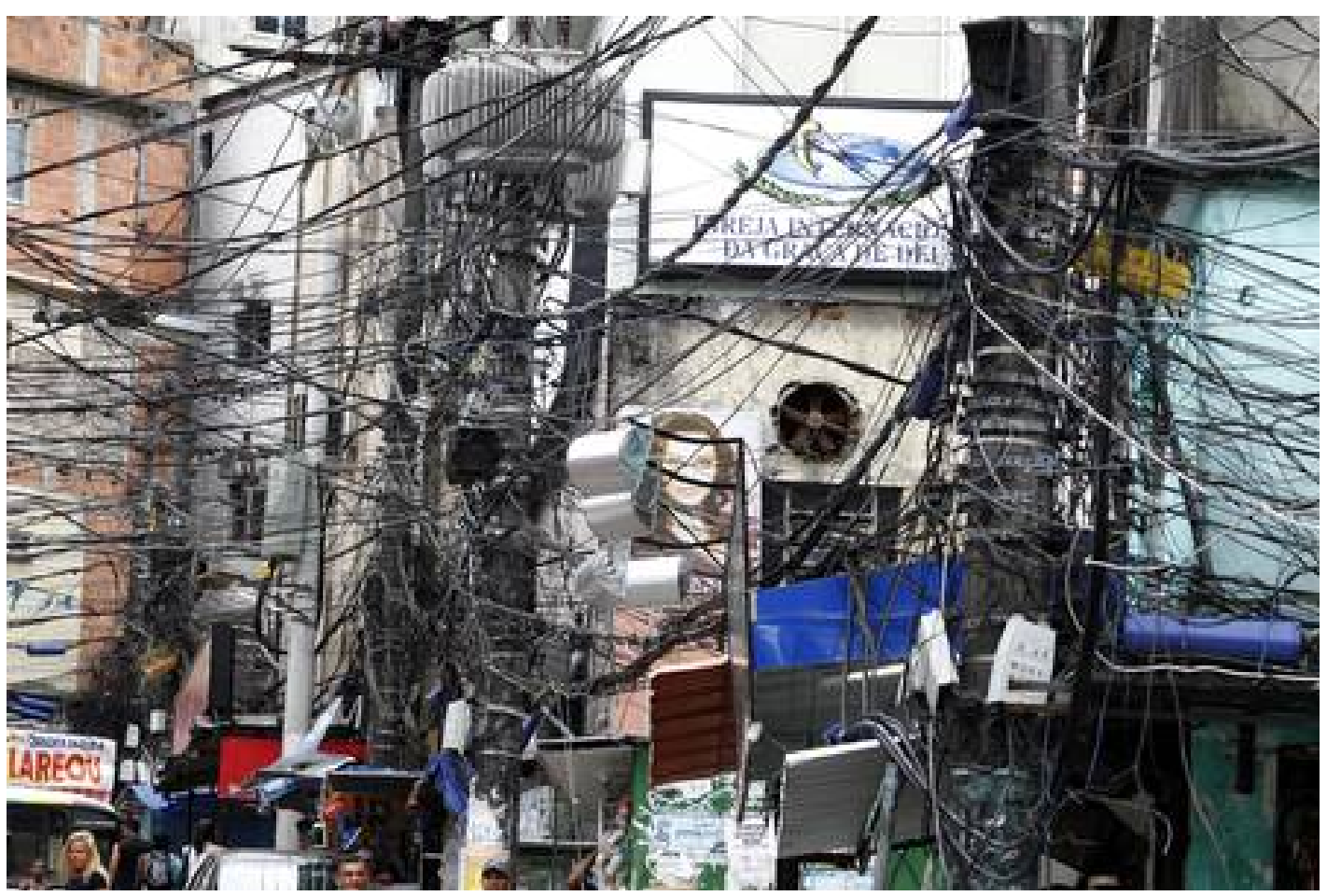

Figura 1: Favela da Rocinha, foto de Roberto Moreyra 
6.

\title{
Catar, escolher e recolher
}

Entre os anos de 2009 e 2010, a diretora teatral Alessandra Vannucci, em parceria com a socióloga Barbara Santos, curinga ${ }^{3}$ do Centro de Teatro do Oprimido, elaborou e produziu o projeto "Laboratório Madalena - teatro das oprimidas"4. Nesse período, mulheres do Brasil, Portugal, Guiné-Bissau e Moçambique experimentaram um laboratório estético com exercícios cênicos especialmente dedicados ao corpo feminino. Os laboratórios produziram seis roteiros que culminaram na criação de diferentes apresentações artísticas, dentre elas a peça teatral "Marias \& Madalenas", fruto do trabalho desenvolvido no laboratório bRazILHA.

Tendo como tema a relação entre o corpo feminino e o trabalho, bRazILHA é o nome da edição desenvolvida com mulheres catadoras de lixo reciclável da Vila Estrutural, cidade satélite de Brasília, com a ideia de montar um espetáculo no qual todos os elementos da cena fossem construídos com e a partir de suas histórias de vida e do lixo encontrado no local. Segundo a diretora da peça, nada foi comprado. Todos os materiais - plásticos, papéis de jornal, ferragens, latas e outros - utilizados para construir cenário, música e figurinos do espetáculo foram encontrados no lixo. Em suas palavras:

\begin{abstract}
bRazILHA é um laboratório estético dedicado ao tema do corpo feminino e do trabalho, desenvolvido com mulheres catadoras de lixo da cidade de Brasília. No laboratório, queremos recolher e devolver ferramentas artísticas às mulheres trabalhadoras, "atrizes" em seu cotidiano
\end{abstract}

\footnotetext{
${ }^{3}$ Curinga é a terminologia criada por Augusto Boal no Teatro de Arena de São Paulo, na década de 1960, para um sistema de atuação no qual atores e atrizes se alternavam entre os personagens. Em seguida, passou a utilizar o mesmo termo para identificar o praticante de seu método que tinha a função de estimular o diálogo teatral nas sessões de Teatro-Fórum. Outras informações sobre o Laboratório podem ser encontradas no blog de Bárbara Santos, em http://kuringa-barbarasantos.blogspot.com/2010/08/laboratorio-madalena-teatro-das.html

${ }^{4}$ Meu encontro com este projeto da diretora e professora Alessandra Vanucci se deu na leitura da monografia de conclusão do curso de graduação em Teatro pela UNIRIO da pesquisadora Fernanda Paixão, a quem sou grata pela inspiração para que eu me debruçasse sobre o gesto de catar, sobretudo em sua relação com o corpo feminino.
} 
contemporâneo, entre a necessidade de repetir todo dia o mesmo papel e o desejo de ser outra. Mulheres que cumprem gestos antigos e vivenciam em seus corpos a memória ancestral de gerações de trabalhadoras engajadas na luta para a sobrevivência no campo, no rio, no cerrado e no sertão. Seu corpo é território marcado pelo trabalho e pela opressão. Seu desejo, sua luta, seus cantos são transformadores. Focamos especialmente uma comunidade engajada em um gesto de trabalho tradicionalmente feminino: o de catar. O gesto de recolher e reutilizar dejetos da natureza assim como urbanos ou industriais, faz parte do cotidiano das mulheres desde os tempos mais antigos. Catar, o que hoje chamamos reciclar, é uma prática de auto sustentabilidade característica de uma economia ecológica e comunitária, tradicionalmente feminina. Este modelo de sociedade se diferencia do sistema patriarcal, fundado na propriedade particular, na divisão do trabalho por gêneros e na exclusão dos dejetos (objetos ou indivíduos). Ela se diferencia pelo fato de fundar o consumo no direito natural (por necessidade e não por possessão) e a convivência na comunidade dos bens e na cooperativação do trabalho. Esta possível sociedade resgataria uma mentalidade pré-histórica matrilinear, muito bem-sucedida na história da civilização humana antes do patriarcado. Por isso, o projeto acontece com catadoras de lixo reciclável que participam da Central de Cooperativas de Brasília. Escrevemos o nome da cidade bRazILHA por entendê-la cidade sem raízes, constituída por pessoas em trânsito, fundada na mitologia da conquista do futuro, representativa do sonho do Brasil e móvel como um navio sem amarras, lançado ao horizonte. bRazILHA. ${ }^{5}$

${ }^{5}$ Release do Laboratório, escrito por Alessandra Vanucci em 2010, encontrado na monografia Laboratório Madalena: derivações de uma experiência cênica. (PAIXÃO, 2012) 


\title{
7.
}

\section{Recolher dentre outras coisas ou um por um}

Catação vem de catar que, consta no dicionário, é um verbo transitivo direto e significa a ação de (1) procurar insistentemente, buscar - o número de um telefone; (2) recolher dentre outras coisas ou um por um; apanhar, pegar-gravetos; (3) tirar e matar (parasitos) de (alguém, algo ou de si mesmo) - piolhos; (4) retirar as impurezas de, limpar, selecionar - o arroz; (5) conseguir (transporte), pegar - catou o último ônibus para Cabo Frio; (6) aplicar uma surra em, bater, sovar - a garotada vai acabar te catando.

\begin{abstract}
Quando percebi que nem São Benedito, nem o arco-íris, nem as cruzes não faziam eu virar homem, fui me resignando e me conformando: eu deveria ser sempre mulher. Mas mesmo semiconformada, eu invejava o meu irmão que era homem. E o meu irmão me invejava por eu ser mulher. Dizia que a vida das mulheres é menos sacrificada. Não necessita levantar cedo para ir trabalhar. Mulher ganha dinheiro deitada na cama. Eu ia correndo deitar na cama da minha mãe, pensando no dinheiro que ia ganhar para comprar pé de moleque. Depois levantava, desfazia a cama com ansiedade, procurando dinheiro.
\end{abstract}

Quando a minha mãe via a cama desfeita, dirigia-me um olhar duro e perguntava:

- O que está fazendo cadela?

- Estou procurando o dinheiro, o Jerônimo disse-me que as mulheres ganham dinheiro na cama, eu deitei e vou ver quanto é que ganhei. Quero comprar doces.

Apanhava. (JESUS, 2014, p.97-98)

Muitas são as passagens de Diário de Bitita em que Carolina conta episódios de violência nos quais era repreendida fisicamente ${ }^{6}$ por sua curiosidade frente às

6 "Minha mãe me espancava todos os dias. Quando eu não apanhava, sentia falta." (JESUS, 2004. P.29) 
desigualdades e injustiças que vivenciava ou ouvia. As inquietações da menina permeiam toda a prosa e aparecem marcadas tanto por descrições frias de situações extremamente violentas, contadas do ponto de vista de uma criança que ainda não entendeu ao certo como funcionam as engrenagens do mundo, quanto por interrogações retóricas que nos convidam a pensar de novo sobre o que já aceitamos como óbvio na vida. Que vantagem tem o homem de nascer se quando ele aprende a viver no mundo já é velho e morre? (p.54), provoca ao escrever, na fase final de sua vida, um livro de memórias com a voz da infância.

Nele, lemos narrativas sobre acontecimentos compreendidos entre 1914, possível data para o nascimento de Carolina Maria de Jesus ${ }^{7}$, e 1937, ano em que definitivamente estabeleceu morada em São Paulo. Tendo como enredo principalmente as suas experiências de menina e jovem mulher e o que observava da vida de seus familiares e vizinhos, o livro apresenta também outras narrativas que buscam oferecer um panorama histórico da sociedade da época. Ao fato de ter sido escrito na fase final de sua vida, soma-se ainda o dado de que Carolina vivia naquele momento o desafio de lidar com a decadência de sua figura pública após ter sido deixada de lado do cenário artístico-intelectual brasileiro, espaço que muito desejou e lutou para conquistar, mas que, em sua fama passageira, pôde ocupar por pouco tempo.

Por isso, o Diário é lido neste trabalho como aposta de que, com ele, Carolina mais uma vez rejeita o 'não' jogado em sua cara ${ }^{8}$, criando, como resposta, um

\footnotetext{
${ }^{7}$ Carolina de Jesus não teve seu nascimento registrado em cartório e por isso sua idade é incerta. Em seus manuscritos a escritora afirma que essa era uma prática comum entre os negros nascidos na antiga cidade escravocrata em que morava e aponta os anos de 1914, 1915 e/ou 1916 como possíveis datas de seu nascimento.

8 Já no prefácio de Casa de alvenaria (1961), segunda publicação de Carolina Maria de Jesus, Audálio Dantas, que promoveu sua carreira ao conhecer a escritora em uma visita que fazia à Favela do Canindé para realizar uma reportagem, decretava violentamente sua morte como autora:
}

Agora você está na sala de visitas e continua a contribuir com este novo livro, com o qual você pode dar por encerrada a sua missão. Conserve aquela humildade, ou melhor, recupere aquela humildade que você perdeu um pouco - não por sua culpa - no deslumbramento das luzes da cidade. Guarde aquelas "poesias", aqueles "contos" e aqueles "romances" que você escreveu. A verdade que você gritou é muito forte, mais forte do que você imagina, Carolina, ex-favelada do Canindé, minha irmã 
inventário de narrativas do terceiro mundo. Nessa construção, cata fragmentos de sua memória para oferecer aos leitores uma coleção de crônicas da sociedade da época, registros históricos, cenas familiares e descrições de injustiças sociais e injúrias raciais vividas e observadas por ela, mas que falam de todo mundo. Por isso, com ela,

[p]ensar a infância, diante do que foi exposto até aqui, pressupõe abdicar das noções de faixa etária ou das noções "infantilizadas" da criança, para concebê-la como um outro, com todas as possibilidades de linhas de fuga e capacidades expressivas. $O$ devir-criança na linguagem poética pode ser compreendido como elo com o elemento lúdico, o desejo, o prazer e o espontaneísmo característico da arte como micropolítica.

(ROLNIK, 2000)

lá e minha irmã aqui. (Prefácio de Casa de alvenaria, escrito por Audálio Dantas)

No entanto, Carolina responde ao silêncio que lhe é imposto, tanto antes quanto depois da publicação de Quarto de despejo, com uma intensa produção artística (da qual apenas pequena parte é conhecida do público) e nega com veemência a imposição de que sua escrita fique restrita à temática denunciante da primeira obra conhecida pelo público. Escreve contos, crônicas, poesias, canções. Ultrapassa o não jogado na cara, como apontou Ana Chiara no seu ensaio "Intelectuais Delirantes". (2008) 
8.

\section{Diga-se de passagem}

Trabalho das passagens ou Passagens, título singelo da publicação brasileira, é considerada por muitos a obra prima de Walter Benjamin. Paris, no século XIX, era uma espécie de prenúncio das grandes metrópoles de todo o mundo e, ao se debruçar sobre ela, Benjamin propôs uma maneira potente de ler e compor pensamentos sobre uma cidade, dedicando seu olhar para as ruínas e restos, no lugar de analisar grandes conquistas ou obras acabadas.

O relacionamento de Benjamin com a capital francesa remonta ao princípio de sua vida em Berlim. Seu pai, um próspero comerciante judeu, ia com frequência a Paris comprar tapetes e antiguidades para revender na Alemanha. Essa atividade profissional paterna, podemos supor, trouxe para a cena de sua infância a convivência com colecionadores de antiguidades, personagem que, como sabemos, é bastante caro ao pensamento benjaminiano, inspirando reflexões e modos de compor uma teoria. O projeto das Passagens é ele mesmo uma coleção de fragmentos da história de Paris ${ }^{9}$. Nele, 4.234 fragmentos elaborados entre 1927 e 1940 são apresentados em 36 arquivos temáticos, organizados de ' $A$ a $Z$ ', em um primeiro bloco, e de 'a a $Z$ ' em um segundo bloco inacabado ou, podemos também dizer, composto por arquivos que ainda estavam vazios, aguardando a inserção de materiais que com o fim de sua vida nunca chegariam a nosso conhecimento.

Talvez o motivo mais recôndito do colecionador possa ser circunscrito da seguinte forma: ele empreende a luta contra a dispersão. $O$ grande colecionador é tocado bem na origem pela confusão, pela dispersão em que se encontram as coisas no mundo. Foi o mesmo espetáculo que ocupou tanto os homens da era barroca; em especial, não se pode explicar a imagem de mundo do alegorista sem o envolvimento passional provocado por esse espetáculo. O alegorista é por

\footnotetext{
9 Uma coleção de fragmentos que compõe uma história já contada por muitos, dirá Benjamin nos arquivos C 1, 6 das Passagens. (p. 122) Uma coleção incompleta, como, aliás, o são todas as coleções.
} 
assim dizer o pólo oposto do colecionador. Ele desistiu de elucidar as coisas através da pesquisa do que lhes é afim e do que Ihes é próprio. Ele as desliga de seu contexto e desde o princípio confia na sua meditação para elucidar seu significado. O colecionador, ao contrário, reúne as coisas que são afins; consegue, deste modo informar a respeito das coisas através de suas afinidades ou de sua sucessão no tempo. No entanto - e isto é mais importante que todas as diferenças que possa haver entre eles -, em cada colecionador esconde-se um alegorista e cada alegorista, um colecionador. No que se refere ao colecionador, sua coleção nunca está completa; e, se lhe falta uma única peça, tudo o que colecionou não passará de uma obra fragmentária, tal como são as coisas desde o princípio para a alegoria. Por outro lado, justamente o alegorista, para quem as coisas representam apenas verbetes de um dicionário secreto, que revelará seus significados ao iniciado, nunca terá acumulado coisas suficientes, sendo que uma delas pode tanto menos substituir a outra que nenhuma reflexão permite prever o significado que a meditação pode reivindicar para cada uma delas. (BENJAMIN, 2009, p. 245.)

O título Passagens, como o próprio autor deixa claro ao longo de sua obra, é referência explícita às passagens parisienses, galerias comerciais surgidas no século XIX que se apresentavam como o primórdio das lojas de departamentos, representando, portanto, importante local de circulação de mercadorias e grande símbolo do avanço do capitalismo. Mas, passagens, como sabemos, são também locais que permitem ao mesmo tempo entradas e saídas. Passageiro, por sua vez, podemos chamar aquilo ou aquele que não se demora e não se fixa. Um pensamento-passagem, então, eu queria aqui arriscar para compor o meu mapa-coleção: aquele que não se demora e não se fixa. Desvia. Permite, como potência, múltiplas entradas e saídas. 
9.

\section{Porque depois pode ficar bonito, uê}

"Porque depois pode ficar bonito, uê" é trecho de "Partida do audaz navegante", que integra o livro Primeiras estórias (1988, p.104-112) de Guimarães Rosa. O conto, narrado em terceira pessoa, justapõe duas histórias: uma que nos conta o narrador, envolvendo quatro crianças (as irmãs Pele, Ciganinha e Brejeirinha, e um primo, de nome Zito), e outra que começa a ser inventada por Brejeirinha em um dia de chuva que fez com que as crianças fossem obrigadas a brincar dentro de casa enquanto a mãe cuidava dos afazeres domésticos.

A história que nos conta o narrador se passa em dois momentos e ambientes. $O$ primeiro acontece do lado de dentro, enquanto chovia e as crianças brincavam perto da mãe, da empregada Maria Eva e da cachorra Nurka. Era um daqueles dias em que parecia não acontecer coisa nenhuma, até que, em meio ao tédio, Brejeirinha começa a recitar frases curiosas e aleatórias ("Tanto chove, que me gela!", "Sem saber o amor, a gente pode ler os romances grandes?"), iniciando, em seguida, a narração em voz alta de uma história inventada. A história de Brejeirinha fala da partida de um "Aldaz Navegante"10, marujo que, em um navio, se lança em alto mar para conhecer outros lugares, deixando em terra todos que ama. A menina, mais jovem entre os presentes, conta empolgada sua história até que é interrompida por Pele: "Você é uma analfabetinha aldaz", provoca a irmã ao criticar sua pronúncia morfologicamente incorreta de menina que ainda está adentrando o mundo das letras, sendo imediatamente apoiada por Ciganinha: "Por que você inventou essa história de tolice, boba, boba?", ao que Brejeirinha, sem pestanejar, responde: "- Porque depois pode ficar bonito, uê!".

Antes que alguém lhe devolvesse resposta, o sol se abre e adentramos com as personagens o segundo momento da narrativa, quando as crianças vão finalmente brincar fora de casa, iniciando uma caminhada em direção ao riachinho. E é ali, em meio à travessia por uma área de pasto, que Brejeirinha

\footnotetext{
10 No conto a grafia de audaz se apresenta na forma 'aldaz' quando proferida por Brejeirinha. À essa escolha do autor suponho uma intenção de marcar no texto a oralidade da menina e/ou, ainda, enfatizar o fato de que, dentre as crianças do conto, ser ela a única ainda não alfabetizada.
} 
recomeça a recitar frases curiosas e decide retomar sua prosa até que, distraída, perde o fio da história, fazendo com que Pele fique impaciente e diga, apontando para um estrume seco de vaca: -"Nã-ão. Não vale! Não pode inventar personagem novo, no fim da estória, fu! E - olha o seu "Aldaz Navegante", ali. É aquele...". No topo do estrume ressequido apontado por Pele havia brotado um cogumelo e a caçula, em um primeiro instante, faz uma careta sentindo-se ofendida. Mas, antes que qualquer outra coisa se desenrole na narrativa, surpreende, abaixando-se para catar do chão florezinhas que acabavam de cair das mãos de Pele, iniciando com elas o processo criativo de dar corpo a sua invenção:

- "Ah! Pois é, é mesmo!" - e Brejeirinha saltava e agia, rápida no valer-se das ocasiões. Apanhara aquelas florinhas amarelas josés-moleques, douradinhas e margaridinhas - e veio espetá-las no concrôo do objeto. - "Hoje não tem nenhuma flor azul?" - ainda indagou. A risada foi de todos, Ciganinha e Zito bateram palmas.

- "Pronto. É o Aldaz Navegante..."-, e Brejeirinha crivava-o de mais coisas - folhas de bambu, raminhos, gravetos. Já aquela matéria, o "bovino", se transformava. (ROSA, 1988, p.110)

A construção da obra de Brejeirinha, a um só tempo plástica e verbal, é resposta inventiva aos deboches de suas irmãs. Partindo da adversidade do momento e utilizando-se das coisas chãs que ali restavam como dejetos orgânicos, a menina inaugura no texto um modo de dizer-agindo que se constrói também na narrativa de Rosa, reinaugurada, no conto, a cada movimento-rompante da menina ${ }^{11}$. É aldaz o navegante e audaz a Brejeirinha. E em que consiste sua audácia se não na potência criativa de fazer arte da merda e de inventar brincando, ao ponto de adentrar sem ressalvas o mundo da criação literária mesmo não sendo ainda alfabetizada $^{12}$ ?

\footnotetext{
11 No conto, a história do dia em que parecia não acontecer coisa nenhuma desdobra-se em outra história a partir da invenção de Brejeirinha. História essa reinaugurada por ela a cada novo gesto de resistir ao silenciamento imposto pelas irmãs, em uma potência criativa que não cessa nunca de jorrar, valendo-se para isso das situações e materiais mais improváveis.

12 Petulância de menina que encontramos também na personagem Bitita narrada por Carolina, diga-se de passagem.
} 
10.

\section{Comer a felicidade com os pés sujos de areia}

Teve aquele dia que você chegou na escola mais cedo como todos os outros dias e ficou quieta no seu canto esperando ansiosamente a hora de poder voltar para a casa. Casa não era bem o nome certo de nenhum lugar ali por perto, fazia tempo tinham todos ido com mala e cuia morar em um lugar que você adorava passar as férias, mas não sabia que ia odiar passar os dias todos. Vocês tinham ido para lá porque seu pai estava construindo um barco. Ele ia construir o barco, vocês iam morar na beira da praia, esperar ele voltar com os peixes e comer a felicidade com os pés sujos de areia. Mas antes dos peixes tinha a escola nova que não ficava perto daquele lugar que você chamaria se pudesse de casa e para chegar nela você ia de carona com uma professora que acho mas não tenho certeza que era amiga da sua mãe porque vocês tinham acabado de chegar naquele lugar e não tinha dado tempo de ficar amiga de ninguém. Ela chegava mais cedo na escola porque era professora igual a sua mãe e você tinha que chegar mais cedo com ela igual acontecia quando morava na sua casa e ia com a sua mãe para a escola de vocês. No caminho de volta daquela escola que não era a sua ela ficava um ponto antes do lugar onde você tinha que descer e você seguia sozinha no ônibus colada no motorista com tanto medo que chegava a faltar o ar e você ia em apneia com o coração gelado de quem pode a qualquer momento perder o tempo certo de descer e não encontrar a mãe e ficar sozinha no mundo procurando ajuda sem ninguém para nada nunca mais e pronto: danou-se a vida. Mas naquele dia aconteceu que você chegou cedo com muita vontade de fazer xixi e a vontade era do tamanho do medo e da vergonha que você tinha de perguntar aonde era o banheiro daquela escola. Então você pensou que se ficasse quietinha quem sabe dava sorte e ninguém percebia que estava ali e o dia terminava mais rápido e você conseguia voltar direito e encontrava a sua mãe no final da tarde e dava tudo certo de novo pelo menos mais uma vez. Só que naquele dia você teve uma vontade grande de fazer xixi e as outras crianças começaram a chegar e deu a hora de começar a aula e ainda tinha a tarde toda pela frente e você foi ficando com mais vontade até que não deu para segurar e você foi para o fundo da sala e xiiiiiiiiiiiiiiiiii: cinco anos e o chão molhado de muita vergonha outra vez. Mas sorte que você tinha um 
casaco na mochila e com aquele casaco limpou o xixi que estava em você na calcinha na calça no chão e ficou torcendo para ninguém perceber, mas falta de sorte que uma criança percebeu e olhou para trás e falou rindo de você que a sala estava fedendo e naquela hora você foi ficando bem pequena para sempre porque assim quem sabe ninguém te percebia e os dias passariam todos mais rápido e você encontraria sempre a sua mãe e tiraria aquela roupa suja e faria xixi no seu útero e não sairia de lá nunca mais. 
11.

\section{Lançar essa força para o mundo}

O devir-criança da/na literatura direciona-se, a partir de Deleuze, não para a infância daquele que escreve, mas para uma infância do mundo.

Não se trata de uma concepção psicologizante da infância, tampouco é chave interpretativa para a leitura crítica de obras literárias. Não é a criança que se torna adulto, não é o adulto que se construiu a partir da criança, é um rompanteadulto-criança que lança o ato de escrever para uma infância coletiva e impessoal.

Está mais ligado ao movimento de ser tomado pela força criança e lançá-la para o mundo. E de onde vem essa força? Da possibilidade de entrar em contado com a potência de estar sempre diante do novo, de viver tantas e quantas vezes a primeira vez?

\footnotetext{
Quem começa vira uma criança. Olha para tudo como se fosse a primeira vez e vê as coisas sem seus nomes e funções conhecidas. Olha para uma garrafa e pensa que é um tipo de fruta ou árvore. Experimenta tudo com a boca. Avança sobre o objeto ou se aproxima com cuidado, temendo que seja perigoso e machuque ou queime. Age com a coisa como se ela também estivesse a descobri-lo. Uma criança está sempre a começar, mesmo quando já conhece algo e já o manipulou continuamente. Na segunda, terceira e quarta vez é sempre como na primeira. A memória não funciona como um amortecedor, um ensinamento que inibe a novidade, mas, ao contrário, funciona como um depósito que supre o mundo com mais novidades. O que é lembrado não serve para diminuir o entusiasmo do encontro, mas para redobrá-lo. Assim, um começo é essa inauguração grandiosa, mesmo se pequena, em que cada instante tem beleza e particularidade. (JAFFE, 2018, s/n)
}

Acordo, olho para o mundo e me espanto: como é que isso funciona? 
E não é isso que o Diário de Bitita nos convida a fazer? Permeado em todas as narrativas por perguntas da infância, questionamentos nada infantis, Carolina de Jesus, lá do alto da sua sabedoria inventiva de criança antiga, nos conduz a uma reflexão dura sobre a desigualdade que constitui a história do Brasil.

Devir-criança na literatura: as forças normatizadoras do poder também agem querendo controlar o corpo das crianças, mas o devir-criança é essa força que resiste, ignora, passa por cima e sobra, resta: brejeirinha ${ }^{13}$.

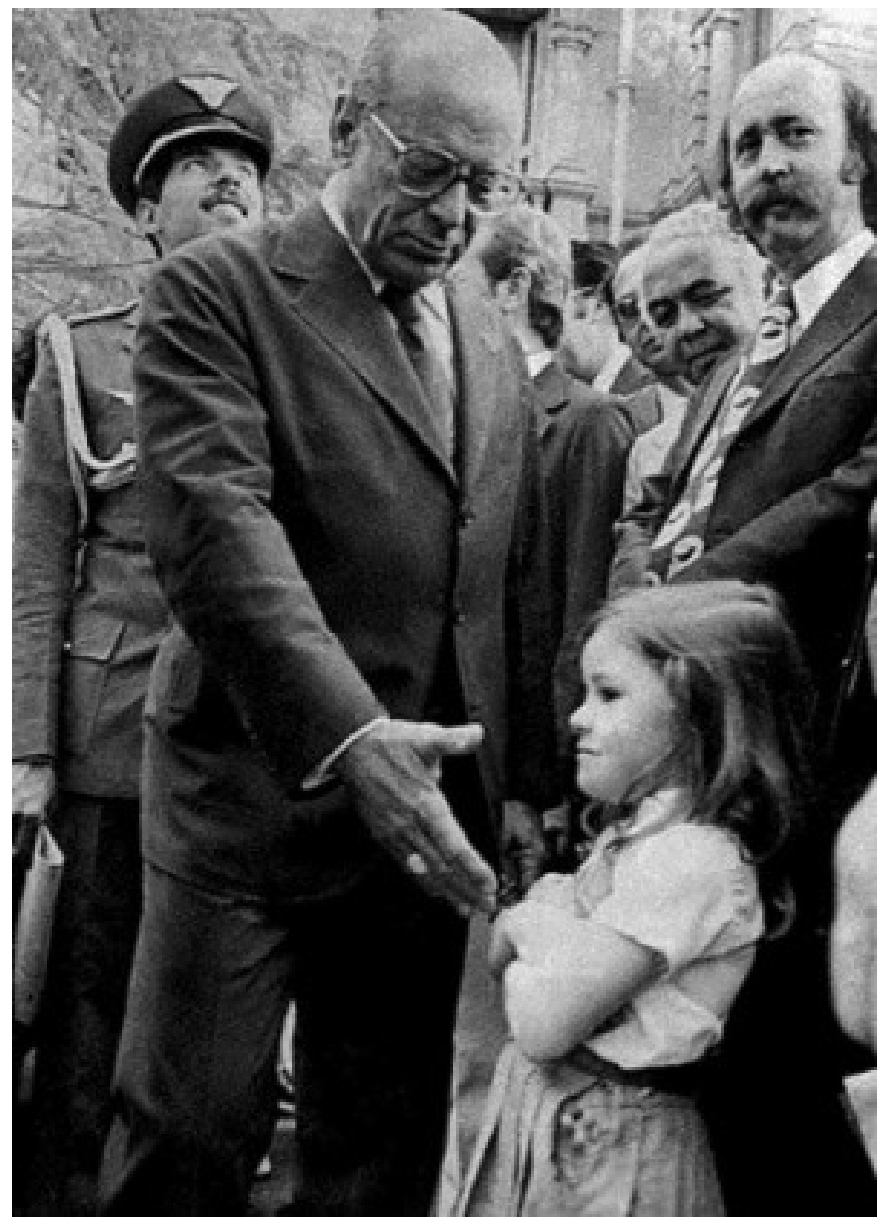

Figura 2: A menina e o ditador, foto de Guinaldo Nicolaevsky

${ }^{13}$ Segundo o dicionário Michaelis, diz-se 'brejeiro' de indivíduo dado a fazer brincadeiras ou gracejos; brincalhão, folgazão, trocista, aquele que se caracteriza por certo jeito maroto. 
12.

Devir-criança, devir-trapeira

As interrogações de Bitita sobre a forma como o mundo funciona me lançam ao texto "O canteiro de obras", de Rua de mão única (2017), no qual Benjamin trata do movimento infantil de desmontar as coisas para ver como são por dentro. Carolina, na fase final de sua vida, convoca com Bitita a força criança de querer desmontar o mundo para ver como funciona. Essa dimensão destrutiva, com Benjamin, apresenta também seu outro lado ${ }^{14}$, devir-trapeira, da gestação de novos mundos a partir dos destroços:

\begin{abstract}
É astucia pôr-se a meditar profundamente, pedantemente, sobre o fabrico de objetos - material didático, brinquedos ou livros - destinados às crianças. Desde o lluminismo que essa é uma das mais rançosas especulações dos pedagogos. A psicologia, que os cega, impede-os de ver como a terra está cheia dos mais incomparáveis objetos de atenção e de exercícios infantis. E dos mais adequados. As crianças gostam muito particularmente de procurar aqueles lugares de trabalho onde visivelmente se manipulam coisas. Sentem-se irresistivelmente atraídas pelos desperdícios que ficam do trabalho da construção, da jardinagem ou das tarefas domésticas, da costura ou da marcenaria. Nesses desperdícios reconhecem o rosto que o mundo das coisas volta para elas, precisamente e apenas para elas. Com eles, não imitam as obras dos adultos, antes criam novas e súbitas relações entre materiais e tipos muito diversos, por meio daquilo que, brincando, com eles constroem. Com isso, as crianças criam elas mesmas o seu mundo de coisas, um pequeno mundo dentro do grande. (BENJAMIN, 2017, p.16)
\end{abstract}

${ }^{14}$ Pensar o devir-trapeiro na infância, pela criação de mundos através de destroços, foi ideia que catei na dissertação de mestrado Cartografias da Infância. (SILVA, 2017) 
13.

\section{Um modo trapeiro de produção de pensamento}

Em Benjamin, o pensar debruçado ${ }^{15}$ sobre as sobras e restos apresenta-se como um modo de produção de pensamento. A busca pelo reconhecimento do rosto do mundo nos resíduos da história é atividade que permeia toda a sua produção crítica dedicada a escovar a história a contrapelo para tecer uma contranarrativa que, em oposição à ideia totalizante de uma história linear e progressiva, contada sempre pelas classes dominantes que não cessam nunca de vencer, faça relampejar, por entre as brechas dos discursos oficiais, o ponto de vista dos vencidos ${ }^{16}$. Para tanto, o crítico materialista propõe que, tal como as crianças, possamos produzir história através do lixo da história (Benjamin, 2002), concentrando nossa atenção nos restos e rastros que o discurso historicista não recorda, uma vez que, quando não temos como objetivo narrar as grandes vitórias já exaustivamente contadas, faz muito mais sentido olhar justamente para tudo aquilo que foi descartado, rejeitado e esquecido pela história oficial.

Esse modo trapeiro de produção de pensamento é notado na crítica benjaminiana tanto pelo seu conteúdo quanto pela sua forma. Se por um lado

\footnotetext{
${ }^{15}$ A ideia de um "pensar debruçado" é posta por Didi-Huberman em seu livro homônimo (2015). Voltarei a falar dela na página 64 desta tese.

${ }^{16}$ Nas palavras de Benjamin:
}

Articular historicamente o passado não significa conhecê-lo "como ele de fato foi". Significa apropriar-se de uma reminiscência, tal como ela relampeja no momento de um perigo. Cabe ao materialismo histórico fixar uma imagem do passado, como ela se apresenta, no momento do perigo, ao sujeito histórico, sem que ele tenha consciência disso. $O$ perigo ameaça tanto a existência da tradição como os que a recebem. Para ambos, o perigo é o mesmo: entregar-se às classes dominantes, como seu instrumento. Em cada época, é preciso arrancar a tradição ao conformismo, que quer apoderar-se dela. Pois o Messias não vem apenas como salvador; ele vem também como o vencedor do Anticristo. $O$ dom de despertar no passado as centelhas da esperança é privilégio exclusivo do historiador convencido de que também os mortos não estarão em segurança se o inimigo vencer. $E$ esse inimigo não tem cessado de vencer. (BENJAMIN, 1987, p. 224-225) 
seu olhar para o corriqueiro da vida, para as ruínas e restos da história, apresenta-se como opção que visa contestar o saber histórico como aquele que se dedica às ditas grandes conquistas da humanidade, a constituição formal de seus ensaios críticos reflete também essa escolha ética ao adotar o fragmentário como gesto escritural que contribui para a constituição de saberes enviesados, não totalitários, que fogem ao didatismo catequizante e convocam o leitor para outro regime da atenção. Nesse sentido, sua escolha pelos escombros não se trata apenas de um tema, mas de um componente constitutivo de uma forma ${ }^{17}$. $\mathrm{E}$ aqui cabe ainda ressaltar o fato de que Benjamin escreve sob impacto das guerras e contra os regimes autoritários da segunda metade do século XX na Europa, sendo marca fundamental de suas reflexões a inserção do sujeito crítico no ato da escrita. Isso porque, ao opor-se radicalmente aos discursos hegemônicos, rejeita, como fundamentação da sua prática de pensamento, a crença em uma crítica política, ideológica ou científica pura, isenta de interesses e pontos de vista:

\begin{abstract}
Trata-se, portanto, de uma postura em relação ao conhecimento que se afasta da posição de alguns dos defensores dos grandes sistemas, que se convencem ilusoriamente da capacidade de eficiência total do que inventam, e humildemente assume a parcialidade inerente ao conhecimento, a subjetividade inevitável que se envolve nele. Considera, então, essa subjetividade não como um problema técnico a ser suprimido, em nome de uma objetividade supostamente neutra; ao contrário, considera-a um ponto de partida capaz de definir humanamente a pertinência de seu trabalho intelectual e de seu modo de encarar a racionalidade. O conhecimento não sustenta a posição falsa e autoritária do poder total, infinito, e assume sua medida humana: nunca inteiramente racional ou inteiramente objetivo, mas sim, marcado pelas circunstâncias do sujeito cognoscente, seus interesses e seus limites; tem; por isso, um caráter necessariamente parcial, fragmentário. (GINZBURG, 2010, p. 82)
\end{abstract}

17 Ginzburg, 2010, p.73. 
14.

\section{Instalação literária, cartografia do caos}

Catando restos da cidade Luiz Ruffato montou, no ano de 2001, um romance de estrutura não linear composto por 70 fragmentos, cujo único elo é o fato de todas as narrativas ocorrerem no dia 9 de maio de 2000, na cidade de São Paulo. Trata-se do livro eles eram muitos cavalos, uma tentativa do autor de encenar, pela escrita, São Paulo, conhecida metrópole de engarrafamentos, conglomerados econômicos e parques artificiais. No livro, não tendo acesso a um narrador que descreva a cidade ou estabeleça uma linha narrativa entre os fragmentos, mergulhamos no caótico território pela colagem de restos da urbe e do relato de histórias acontecidas em um dia na vida de diferentes anônimos que lá habitam. Como uma instalação literária - definição apresentada em diferentes momentos pelo escritor para caracterizar sua obra - somos expostos a um emaranhado de fios que compõe o mapa da cidade.

Primeiro livro publicado pelo autor sob a categoria romance, a obra se apresentou como peça inaugural de um projeto literário que viria a ser conhecido posteriormente pelo público. Com a publicação de Inferno Provisório, coleção composta por 5 livros que também trazem a cidade de São Paulo como cenário, fomos apresentados ao declarado interesse do autor de intervir politicamente na realidade por meio da tematização de personagens comumente apagados nas narrativas literárias: a classe operária.

No entanto, apesar da explícita escolha temática, o engajamento de seu projeto não se define tanto pelo conteúdo quanto pela escolha formal de procedimentos estéticos que assumem a fragmentação como estilo e a precariedade como sintoma ${ }^{18}$ de época. É o que observamos na ardilosa utilização de artifícios formais já considerados comuns em parte da produção contemporânea, como a incorporação de uma linguagem previamente considerada não-literária (horóscopos, listas e santinhos, por exemplo), o uso de formas breves, a

18 Ver http://www.conexoesitaucultural.org.br/wp-content/uploads/2010/05/da-impossibilidadede-narrar.pdf. Acesso em 03/09/2019 
utilização de bricolagens, a escassez de pontuação e a mistura de vozes narrativas. Com Ruffato, em uma leitura benjaminiana, temos a explícita potencialização desses recursos como forma não apenas de criar efeitos de realidade, mas também de, a partir de uma compreensão da escrita como potente campo de experiência política, resistência estética e abertura de frestas, romper com a reprodução formal de um discurso de orientação hegemônicoburguesa:

(...) o romance tradicional, tal como o conhecemos, nasce no século 18 como instrumento de descrição da realidade do ponto de vista de uma classe social ascendente, a burguesia. Ou seja, o romance ideologicamente serve a uma visão de mundo específica. Como usar a forma sem trair o conteúdo? (RUFFATO, 2008, p. 321). 
15.

\section{A escrita-trapeira de Carolina de Jesus}

Tendo vivido em meio a uma realidade de escassos recursos materiais, a experiência trapeira de Carolina de Jesus extrapola sua atividade de subsistência e transmuta-se em potência inventiva de vida. Seu fazer literário justapõe registros da tradição oral às palavras rebuscadas que a escritora cata no cânone, costura lampejos de seu passado aos fatos históricos e comentários políticos que recolhe das conversas que escuta nas ruas e encontra nas páginas de jornais e revistas retirados no lixo.

Marcados por uma escrita não linear, os dois livros da autora apresentados neste trabalho são também caracterizados pela composição em fragmentos e toda sua obra registra uma pluralidade discursiva que não se limita ao tradicional enquadramento de gêneros. Mas, enquanto na crítica benjaminiana o elo formaconteúdo se dá como um posicionamento político de domínio da forma, a obra de Carolina parece tecer esse híbrido-fragmentar justamente porque inaugura um campo de experimentação artística da palavra por parte de membros das margens da sociedade, em uma época onde o contato com os diversos níveis da cultura se dava pela forma fragmentária, aquela que era possível aos que improvisavam instrumentos para ingressar no campo da arte.

Em sua escrevivência ${ }^{19}$, esse mosaico que compõe o texto se produz também por um insistente movimento de observar, selecionar e recolher inerente ao fazer artístico e filosófico. Na obra de Carolina, leio a sobreposição da poeta à da trapeira tal como pensou Baudelaire: é enquanto a burguesia dorme seu sono dos justos que ela se recolhe à cata de rimas, dedicando as noites ao seu fazer literário que é arte e potência e sonho de ascensão na vida. Não há, no entanto, em sua obra nenhuma indicação de incômodo com os gêneros tradicionais, nem tampouco o escrúpulo da mercantilização das Letras que tanto incomodou o poeta do Segundo Império.

${ }^{19}$ Escrevivência é um conceito criado por Conceição Evaristo para dar conta [d]a escrita de um corpo, de uma condição, de uma experiência negra no Brasil. (Evaristo, 2007, p.20) 
Ao contrário. Em Carolina lemos admiração pela tarefa do escritor e empenho em incluir-se nela. Sua escrita quis ser grande, ficar rica, viver a beleza, comprar uma casa e sair da favela. Sua arte é também vingança e lá do lixão ela grita: as rascôas da favela estão vendo eu escrever e sabe que é contra elas. (JESUS, 1976. p.15) 
16.

\section{Ler com outros sentidos, ruído}

Sexta-feira, final da tarde. O dia é 10 de junho de 2016, estamos na Rocinha para participar de um evento que se apresenta como uma ação sonoro-visual sobre paisagens culturais e memórias da favela. É hora do rush. O trânsito usualmente caótico se intensifica ainda mais. São trabalhadores que voltam da labuta diária, estudantes que regressam da escola, moto-taxistas que se aglomeram pelas ruas, transeuntes que passeiam por becos e vielas. $O$ final de semana se aproxima.

Sentamos um pouco distante, ainda cansados do caos que havíamos encarado para atravessar a cidade, observando a movimentação não apenas da Praça da Rua 4, mas também dos seus arredores. Do lado de cá é possível perceber que,

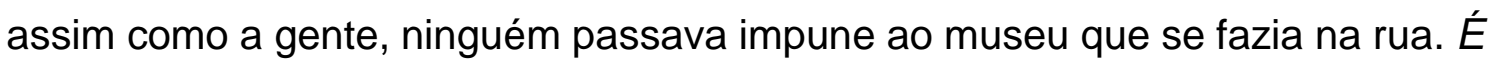
preciso trabalhar memória e história fora de uma caixinha comentou em outra ocasião Antônio Carlos Firmino, morador da Rocinha, geógrafo de formação e museólogo orgânico, como costuma se apresentar. E ali, fora da caixinha, uma televisão havia sido colocada estrategicamente em cima de um carro para, com o auxílio de quatro caixonas de som, exibir a céu aberto um curta-metragem sobre a memória da favela. A instalação, como era fácil perceber, destoava do cenário habitual do lugar e chamava a atenção de todos. Além do vídeo, compunham também a ação áudios espalhados pela Praça com relatos de moradores sobre histórias de suas vidas e monóculos que guardavam em seu interior trabalhos antigos dos fotógrafos Marc Ferrez e Augusto Malta, apresentados em contraste com fotos recentes da Rocinha.

Tentei assistir ao curta, mas minha atenção se fazia dispersa frente aos muitos sons que eu ouvia. No entanto, foi ali, entre uma e outra tentativa de concentração, que me peguei pensando na escolha feita pelo Museu Sankofa História e Memória da Rocinha, idealizador da iniciativa, por apresentar a intervenção como uma ação que, além de visual, se nomeava sonora: para o corpo a corpo com quais ruídos havíamos sido convidados a entrar em contato? 
17.

\section{Persiste, gruda e suja, deixa um resto}

No dia 28 de julho de 2011, aos 72 anos, morreu Estamira Gomes de Souza, catadora de lixo internacionalmente conhecida por ter se tornado personagemtítulo do documentário homônimo. Lançado no Brasil em 2005, o filme rodou o mundo recebendo prêmios aqui e lá fora, e apresentou a todos a vida e força de uma mulher que, na época, tinha pouco mais de 60 anos, 22 deles vividos no lixão.

A história do documentário começou quando o diretor Marcos Prado, em visita ao aterro de Gramacho para uma sessão fotográfica, viu Estamira se aproximar e dizer para ele que tinha a missão de revelar a verdade. Diante da lucidez contida no discurso caótico da catadora, Prado voltou várias vezes ao lixão para registrar seu cotidiano e produziu, segundo costuma mencionar em entrevistas, um filme buscando organizar os fragmentos de seus vários mundos e histórias. O resultado que vemos nas telas, no entanto, em nada se parece com um discurso organizado, que nos aproxime de uma ideia de ordem (ou progresso). Muito pelo contrário. Em Estamira ouvimos a louca do lixão vociferar aos quatro ventos suas mágoas contra um Deus estuprador, a desordem do mundo e a falácia de seus médicos copiadores de receitas. E, embora os surtos de raiva registrados no filme tenham sido rapidamente associados pelo público ao seu diagnóstico de esquizofrenia e as análises que elabora em língua própria costumem ser entendidas como mistura entre as vozes que ela dizia escutar do além e os registros de sua memória, nada em Estamira é de fácil interpretação. Distante dos discursos ecologicamente corretos sobre reciclagem e reaproveitamento que tão em voga circulam por aí $^{20}$, o que essa catadora faz

\footnotetext{
${ }^{20}$ Sobre os discursos ecologicamente corretos relacionados à reciclagem e ao reaproveitamento de resíduos destaco essa passagem de Italo Calvino:
}

No rito do jogar fora gostaríamos, eu e o lixeiro, de reencontrar a promessa do cumprimento do ciclo, própria do processo agrícola, em que - conta-se - nada se perdia: o que estava sepultado na terra tornava a brotar. (Eis que a conversa toma o caminho da evocação arcaica e ninguém mais vai conseguir detê-la.) Tudo se desenrolava no mais simples e regular dos modos: depois de sua temporada subterrânea, a semente, o adubo, o sangue dos sacrifícios voltavam à luz com a nova colheita. Agora a indústria 
com o lixo é jogá-lo de volta em nossa cara. E foi assistindo ao documentário que senti forte a ideia de que a noção de resto convocada nesta escrita passa por tudo aquilo que é descartado, rejeitado e esquecido, mas que não é só isso. Tem teorias, obras, pessoas e objetos, que passam pela gente e deixam um resto. É como se voltassem sempre em momentos inesperados. E Estamira não se cala. Seu pensamento excede, traz um argumento a mais que incomoda, se inscreve na gente. Persiste, gruda e suja, deixa um resto.

multiplica os bens mais que a agricultura, mas o faz mediante os lucros e os investimentos (...). Inutilmente entornamos, eu e o lixeiro, nossa obscura cornucópia, a reciclagem das sobras pode ser apenas uma prática acessória, que não modifica a essência do processo. O prazer de tornar a fazer nascerem as coisas perecíveis (as mercadorias) permanece sendo privilégio do deus Capital, que monetiza a alma das coisas e no melhor dos casos só deixa para nosso uso e consumo os restos mortais. (CALVINO, 2000, p.91-92) 
18.

\section{Como excrever uma tese?}

Tecendo uma crítica à concepção maniqueísta de classificar os homens entre seres puros e limpos ou sujos e pecadores, Italo Calvino, em sua Poubelle agréée, associa o movimento de levar o lixo para fora de casa a um ritual coletivo de purificação praticado diariamente pelos moradores das grandes cidades. Para ele, o ato que comumente passa despercebido traria consigo uma ampla gama de significação, tratando-se tanto de um acordo municipal para que os órgãos responsáveis livrem as cidades de seus resíduos ao final de cada dia, quanto de um rito simbólico de limpeza, espécie de vício estrutural da mente católicoitaliana (CALVINO, 2000, p. 87) da qual somos herdeiros.

No decorrer do ensaio, Calvino apresenta a ideia de que o alívio e o prazer que sentimos ao nos livrar de nossas escórias está diretamente relacionado ao fato de associarmos a sujeira ao pecado. O ritual de purificação seria, assim, mais um mecanismo de controle que molda a vida daqueles que estão sob o contrato social higienista, removendo qualquer sujeira ou sinal ${ }^{21}$ que pudesse singularizar sua própria experiência para, desse modo, reinscrever nos corpos uma história limpa, oficial.

\footnotetext{
$O$ ato de levar para fora a poubelle deve portanto ser interpretado simultaneamente (pois assim eu o vivo) sob os aspectos de contrato e de rito (dois aspectos ulteriormente unificáveis, na medida em que todo rito é contrato, mas por enquanto não quero - contrato com quem? - ir tão longe), rito de purificação, abandono das escórias de mim mesmo, não importando se se trata exatamente daquelas escórias de mim mesmo, contidas na poubelle ou se aquelas escórias remetem a qualquer outra possível escória minha; o que importa é que nesse meu gesto diário eu confirme a necessidade de me separar de uma parte do que era meu, os despojos ou a crisálida ou o limão espremido do viver, para que reste só a
}

\footnotetext{
${ }^{21}$ Em uma exigência de limpeza que se impõe principalmente para as mulheres, portadoras do pecado original, cujos corpos, transformados com facilidade em mercadoria, não devem conter quaisquer marcas, manchas, rugas ou imperfeições corporais (sob o preço de caírem de cotação no mercado).
} 
essência, para que amanhã eu possa me identificar por completo (sem resíduos) no que sou e tenho. Apenas nesse jogar fora eu posso me assegurar de que algo de mim ainda não foi jogado fora, e talvez não seja nem venha a ser para jogar fora.

A satisfação que sinto é portanto análoga à da defecação, de sentir as próprias vísceras se desimpedindo, a sensação, ao menos por um instante, de que meu corpo nada mais contém do que a mim, e não há confusão possível entre o que sou e o que é estranheza irredutível. (CALVINO, 2000, p.85-86)

A confusão entre o sujeito e seus excrementos não é, no entanto, exatamente uma novidade. Na teoria freudiana, temos o ato de defecar como a primeira expressão das relações de negociação de uma criança. É o momento em que, através do controle dos esfíncteres, ela pode pela primeira vez recusar ou responder afetivamente às expectativas da mãe, oferecendo-Ihe como presente uma parte do seu corpo ou a sua hostilidade, retendo suas fezes em gozo próprio. Mas, ao nos conduzir em seu ensaio a uma comparação entre o ato de escrever e o ato de levar o lixo para fora ao prazer de despojar-se de suas excreções, Calvino nos presenteia com uma virada conceitual que tanto retira a literatura das altas esferas, quanto oferece a possibilidade de lermos a escrita como renúncia a um pedaço do corpo do autor que se lança para a exterioridade, inscrevendo-se fora. A ideia de uma escrita que se inscreve fora, por sua vez, nos aproxima da palavra-conceito ex-crita, desenvolvida por Jean-Luc Nancy que, tocado pelo texto de Georges Bataille, escreve com ele:

Trata-se de escrever ali como aqui "em comunidade com Georges Bataille". "Escrever" se escrevendo nesse caso a partir do lugar de uma exterioridade marcada pelo prefixo ex-, portanto excrever. Escrito, como "excrito" (excrit), a que se junta o sentido homófono de "ex-grito" (cri, em francês). Escrever, para Georges Bataille, ou ex-crever, implica em um equívoco essencial: escreve-se sempre o grito (e não "sobre" o grito), a vida, a "coisa em si", o ser, ou seja, aquilo que por definição não se escreve, que prescinde e exclui qualquer possiblidade de escrever. Ex-crito, quer dizer, escrito fora, em uma exterioridade que, no entanto, não remete a um referente, por exemplo, a vida de Georges Bataille, mas a algo que se 
inscreve (ou ex-creve) sempre e apenas na ex-crita. (NANCY, 2013, p.312)

Excrever, inscrever-fora, é, para Nancy, uma questão de tato, de toque, uma produção que a escrita gera como sua outra face. Estando simultaneamente dentro e fora, a excrita é corpus textual expelido do corpo do autor que se inscreve naquele que lê, nutrindo-o para logo ser também expelido e posto de volta em circulação. É, enfim, o que resta de uma escrita, onde [j]á não há alto, nem baixo, céu ou inferno, somente esse corpo excrito que pelo toque estabelecido pelas palavras viabiliza um ponto de encontro, de intersecção, de contato $^{22}$ :

\begin{abstract}
Sem dúvida que o corpo é o facto que se escreve, mas não é de modo algum onde se escreve, nem sequer aquilo que se escreve mas sempre o que a escrita excreve. Só há excrição através da escrita, mas o excrito resta, esse outro bordo que a inscrição, mesmo continuando a significar sobre um bordo, se obstina em indicar como seu outro-próprio bordo. [...] Torna-se evidente que devemos compreender a leitura não como uma decifração, mas como o tocar e o ser tocado, o contacto com as massas do corpo. Escrever, ler, questão de tacto. (NANCY apud LAZZARETI, 2019, p.22)
\end{abstract}

Um encontro com Estamira? Com Carolina? Na PUC, na Rocinha? Nancy me toca: seria possível escrever com o lixo, em comunidade com (e não sobre) elas? 
19.

Manchas na pele, linguagem ${ }^{23}$

Um gato deitado em cima de um computador surge em primeiro plano na tela e apresenta aos espectadores o nome do filme: 'Les glaneurs et la glaneuse ${ }^{24}$ '. A câmera de Agnès Varda dá um close em seus olhos que nos encaram diretamente. Em seguida, os créditos do filme aparecem sobre um plano de fundo formado por enciclopédias postas lado a lado. Uma delas se abre: estamos na letra G e a voz da narradora lê as definições de 'glanage', 'glaner', 'glaneur' e 'glaneuse' que aparecem ao lado da reprodução do quadro 'Des glaneuses', de Jean-François Millet (1857):

G de 'Glanage' [respiga].

Respigar é apanhar os restos, depois da colheita.

Respigador, ou respigadora, é alguém que respiga.

(o gato roça seu pescoço na enciclopédia)

Antigamente, apenas as mulheres respigavam.

A célebre pintura de Millet aparece em muitos dicionários.

O quadro original está no Museu D’Orsay.

Enquanto ouvimos a narração transcrita acima, somos postos diante de um jogo de cena construído pelo pareamento de imagens da reprodução da obra na enciclopédia e de seu original no Museu D'Orsay em Paris, que aparece sendo observado e fotografado pelo público. Em seguida, do frame que apresenta o original de Millet, passamos para a imagem do gesto de catar atualizado no corpo de uma camponesa que, em depoimento para a câmera, se recorda do tempo em que respigava sobras da colheita junto com suas vizinhas e se abaixa, performando para a câmera o modo como outrora colhia as sobras e guardava no avental.

\footnotetext{
${ }^{23}$ Machas na pele, linguagem é título do primeiro ensaio do livro Ó, de Nuno Ramos. (2008)

24 'Les glaneurs et la glaneuse', traduzido ao pé da letra, significa "Os respigadores e a respigadora". Esta distinção de gênero entre os respigadores e a respigadora não foi traduzida para o português. Nossa versão recebeu o título 'Os catadores e eu' e aqui a presença performativa de Agnès Varda é dada desde o início: ela é também uma catadora.
} 
O gesto de catar conduz toda a narrativa do documentário. Respigar é direito garantido na França. Lá, desde os tempos mais remotos, os respigadores são autorizados por lei a entrar nas propriedades privadas depois da colheita e catar os alimentos que por algum motivo estão fora do padrão e não se transformaram em mercadorias selecionadas para comercialização. O mesmo acontece nos centros urbanos quando, ao final da feira, os respigadores podem coletar a xepa e ao final do dia, quando podem retirar dos montes de lixo aquilo que necessitam. É a esse modo de vida que o documentário de Varda se dedica. Ao longo do filme, a realizadora pega a estrada com a câmera na mão, apresentando aos espectadores a vida de diferentes catadores urbanos e rurais, convidando-nos a debruçar nosso olhar para ver aqueles que se curvam em busca do que foi rejeitado.

Mas não é só isso.

No filme, o movimento de olhar para baixo e recolher aquilo que dentre as sobras se sobressai é apresentado como memória ancestral repetida milhares de vezes nos corpos das mulheres e transmitida, com o passar do tempo, também para os corpos dos homens. E o corpo de Varda, narradora-catadora da trama, é parte importante dessa história. Sua catação nos oferece uma coleção de objetos de pesquisa que se desdobra em diferentes cenas. Passamos pela obra de Millet e por entrevistas com diversos catadores e catadoras que catam por necessidade, por filosofia de vida ou porque são artistas e buscam material para a criação de suas obras. Mas passamos também por cenas da própria diretora filmando suas mãos, rugas e cabelos brancos. Isso porque, ao lado das imagens de catadores que recolhe, Varda, ao parar a câmera em partes do seu próprio corpo, inclui tomadas que marcam o tempo passando por ela. E, com esse recurso, oferece aos espectadores uma espécie de quebra na sequência narrativa, convidandonos a pensar com ela sobre as relações existentes entre o gesto de catar, o processo de construção de uma narrativa cinematográfica e a passagem do tempo como história inscrita nos corpos por suas rugas e manchas (na pele, linguagem). 
20.

\section{Bolsa de cacarecos}

Dimensão que nessa escrita caminha ao lado do movimento de recolher: aquela ligada ao tempo e à memória ${ }^{25}$. Coletar para lembrar, dirá Agnès Varda ao final d'Os catadores e eu, enquanto mexe em diferentes objetos guardados em uma caixa de coisas que catou durante uma viagem ao Japão. Memória implica esquecimentos e lembranças, é resultado dessa complexa relação. Em off, ouvimos a narradora dizer 'recolher fatos, gestos, informações' e, ao contar sobre a sua dificuldade de fazer de outra maneira, a recolha é apresentada por ela como um percurso de memória. A história da viagem será a sua caixacoleção.

Por aqui, seleciono materiais diversos para juntar os fragmentos-resto que vão dando corpo a esta tese em forma de coleção. Nela, o gesto de catar aparece como movimento que une temporalidades diferentes, traça o mapa, perpassa gerações, recolhe lembranças, constrói o corpus de investigação. O colecionador é, para Benjamin, aquele que transfigura as coisas, retirando-as de circulação e destituindo-as, assim, do caráter de mercadoria.

Nesta pesquisa, a recolha é também um debruçar-me em vadiagem de pensamento $^{26}$ sobre materiais diversos, como o faria uma criança ou um

\footnotetext{
${ }^{25}$ Aqui sigo a proposição de Walter Benjamin, que valoriza a memória enquanto experiência, como destacado por Jeanne Marie Gagnebin, no prefácio de Magia e técnica, arte e política: ensaios sobre literatura e história da cultural (1987):
}

Nos textos fundamentais dos anos 30 , que eu gostaria de citar mais longamente, Benjamin retoma a questão da "Experiência", agora dentro de uma nova problemática: de um lado, demonstra o enfraquecimento da "Erfahrung" no muundo capitalista moderno em detrimento de um outro conceito, a "Erlebnis", experiência vivida, característica do indivíduo solitário; esboça, ao mesmo tempo, uma reflexão sobre a necessidade de sua reconstrução para garantir uma memória e uma palavra comuns, malgrado a desagregação e o esfacelamento social. (p.9) 
trapeiro ${ }^{27}$, para desses encontros disparar articulações e fazer acontecer o trabalho ensaístico.

\begin{abstract}
O ensaio, porém, não admite que seu âmbito de competência the seja prescrito. Em vez de alcançar algo cientificamente ou criar artisticamente alguma coisa, seus esforços ainda espelham a disponibilidade de quem, como uma criança, não tem vergonha de se entusiasmar com o que os outros já fizeram. O ensaio reflete o que é amado e odiado, em vez de conceber o espírito como uma criação a partir do nada, segundo o modelo de uma irrestrita moral do trabalho. Felicidade e jogo the são essenciais. Ele não começa com Adão e Eva, mas com aquilo o que deseja falar; diz o que a respeito the ocorre e termina onde sente ter chegado ao fim, não onde nada mais resta a dizer: ocupa, desse modo um lugar entre os despropósitos. (ADORNO, 2003, p.16-17)
\end{abstract}

Ou então:

É que quando menina pequena eu saia todo dia com uma bolsa a tiracolo. Não era uma bolsa qualquer: guardava nela tudo que encontrava no chão da rua e que por qualquer motivo me despertava interesse. Andava catando brinquedos para a minha coechão. Por motivos que só mais tarde entendi, minha mãe achava essa catação o maior barato. Era um tesouro nosso a minha bolsa de cacarecos.

${ }^{27}$ Trecho retirado de 'Atlas - como levar o mundo às costas?', texto de apresentação de Georges Didi-Huberman da exposição homônima, escrito quando esteve em cartaz no Museu Reina Sofía: 


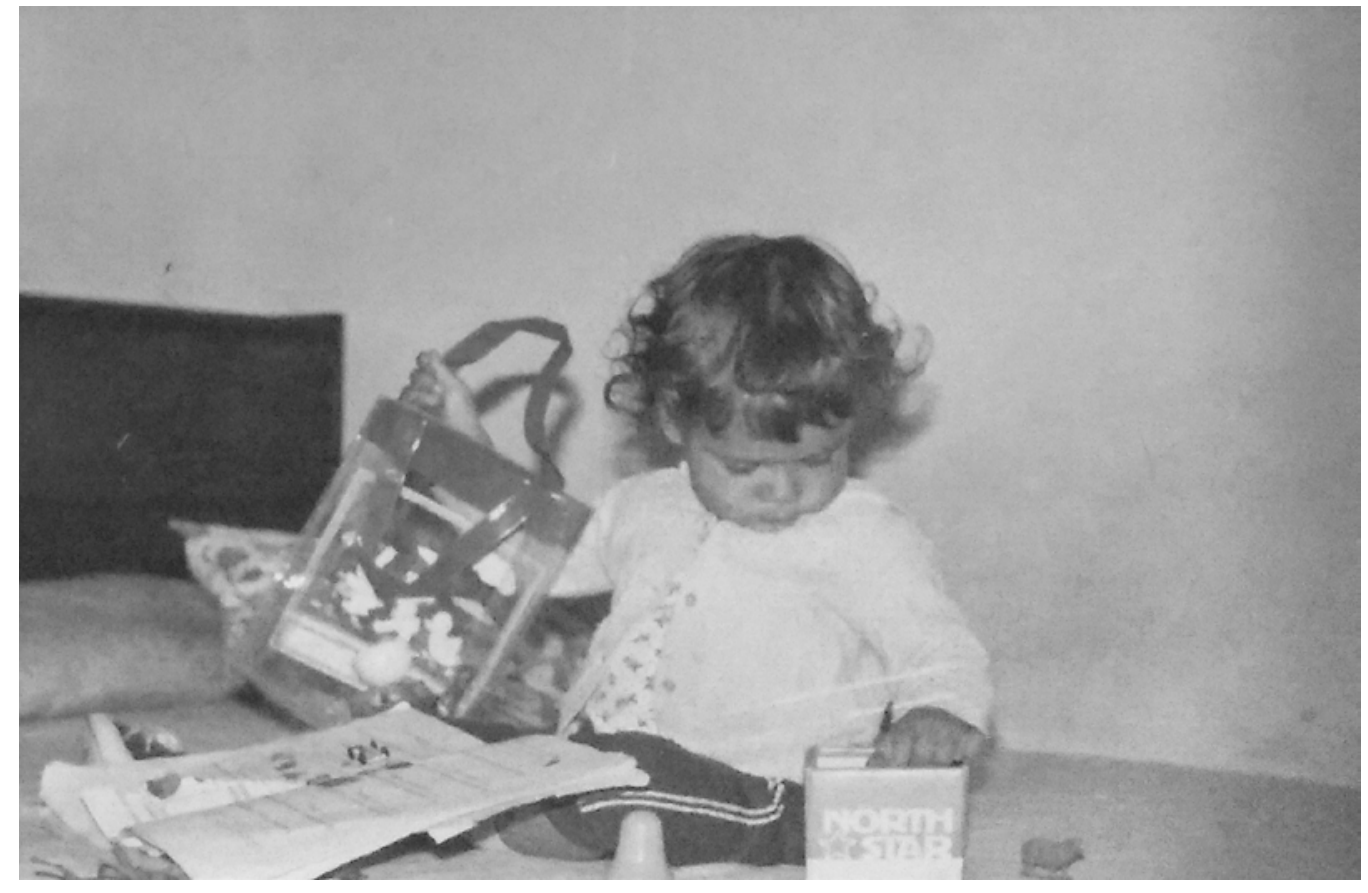

Figura 4: Bolsa de cacarecos

ป 
21.

\title{
Coletar para lembrar
}

\begin{abstract}
Há um quadro de Klee que se chama Angelus Novus. Representa um anjo que parece querer afastar-se de algo que ele encara fixamente. Seus olhos estão escancarados, sua boca dilatada, suas asas abertas. $\mathrm{O}$ anjo da história deve ter esse aspecto. Seu rosto está dirigido para o passado. Onde nós vemos uma cadeia de acontecimentos, ele vê uma catástrofe única, que acumula incansavelmente ruína sobre ruína e as dispersa a nossos pés. Ele gostaria de deter-se para acordar os mortos e juntar os fragmentos. Mas uma tempestade sopra do paraíso e prende-se em suas asas com tanta força que ele não pode mais fechá-las. Essa tempestade o impele irresistivelmente para o futuro, ao qual ele vira as costas, enquanto o amontoado de ruínas cresce até o céu. Essa tempestade é o que chamamos progresso. (BENJAMIN, 1987, p.226)
\end{abstract}

Trabalhar com memória é estar de alguma forma envolvido com a morte ${ }^{28}$, algo como estar situado entre a busca por uma forma de sobrevivência frente ao apagamento do tempo e o gesto esperançoso de acolher o esquecimento como abertura a uma vida por vir.

Na favela da Rocinha de hoje o movimento de trabalhar com a memória se faz fortemente presente e tem como símbolo a imagem de um pássaro mítico que está com os pés plantados firmemente para frente e com a cabeça olhando para trás. É Sankofa, uma palavra da língua Akan, originária das nações africanas de Gana e da Costa do Marfim, que nomeia o Museu Sankofa de História e Memória da Rocinha e significa: [d]evemos olhar para trás e recuperar nosso passado, assim podemos nos mover para frente. Assim compreendemos por que e como viemos a ser quem somos nós, hoje 29 .

28 Trecho recolhido da Tese de doutorado $A$ escuta de memórias nos labirintos da favela: reflexões metodológicas sobre uma pesquisa-intervenção. (CARVALHO, 2015)

${ }^{29}$ Informação disponível no site do projeto 'Memória Rocinha' (http://memoriarocinha.com.br/), desenvolvido pelo Museu Sankofa Memória e História da Rocinha em parceria com o Instituto Moreira Salles (IMS), com o objetivo de contribuir para a compreensão dos processos de transformação da paisagem social e urbana da Favela da Rocinha e do seu entorno ao longo de mais de um século de história. 
O museu se apresenta como uma iniciativa que, mantendo os olhos virados para o futuro, tem o objetivo de olhar para a memória da favela. Sua existência começou a ser pensada enquanto instituição museológica há dez anos ${ }^{30}$. A práxis de trabalhar a memória local da Rocinha existe, no entanto, desde a década de 1970, quando os alunos de um curso de alfabetização para adultos, provocados pela sua então professora Lygia Segalla, saiu às ruas para pesquisar, andando pelos becos e vielas da favela, as histórias de vida dos seus vizinhos.

Esse exercício criativo, que conheci enquanto trabalhava na Biblioteca Parque da Rocinha, durou dois anos e deu origem ao livro Varal de lembranças Histórias da Rocinha. Durante o período, o grupo buscou catar histórias em diferentes pontos da favela, contando com o apoio e participação de redes e associações de moradores. As histórias foram recolhidas por meio de entrevistas e enriquecidas com a coleta de fotos, documentos, cartas e recortes de jornal:

\footnotetext{
Uma tábua, um pedaço de lata, uma banda de pneu, uma telha de papelão.
}

Se martela, se cola com piche, se amarra com arame, com corda. Ajeita o sopapo, planta os pés do barraco.

Cava o chão, bota as colunas, enche as sapatas, alinha tijolo, vira laje, assenta portas, janelas, emboça paredes, pinta.

O nosso livro nasceu devagar. Uma história, outra, mais outra. Um fragmento de carta, um retrato de álbum, uma poesia, um folheto, uma música, um recorte de jornal.

\footnotetext{
${ }^{30}$ A ideia de manter vivas a memória e a história da Rocinha remonta aos anos 70 com a criação de um grupo formado inicialmente por sete moradores. Anos depois, na década de 90 , houve nova tentativa de se criar o Núcleo de Memória e História e, embora a proposta não tenha seguido adiante, a movimentação reascendeu a discussão sobre o direito à Memória e História na/da comunidade. Também quase 20 anos depois, após a realização do Fórum Cultural da Rocinha (2007), surgiu o grupo pró-museu da Rocinha (2008), composto por diversos representantes de instituições e atores locais. É no ano de 2011 que, finalmente, o grupo prómuseu da Rocinha foi considerado pelo Programa Pontos de Memória/Instituto Brasileiro de Museus (Ibram/MinC) como Ponto de Memória. (Fonte: Site Museus do Rio, Acesso em 17/11/2018)
} 
Fomos emendando essas lembranças, esses guardados. (1983, p.4)

Depois de selecionados, todos os depoimentos e documentos foram organizados no formato de um livro que, no lugar de capítulos, apresenta suas alas, e constrói a obra no potente paradoxo de contar memórias muitas vezes duras e de extrema violência pelo enquadramento festivo de um desfile de carnaval. 
22.

\title{
Entre o excesso e a falta
}

\author{
Minha vida é um livro aberto. Ah! Se eu for contar quantos \\ homens já tive na vida...
Vim pra cá em 1958, quando eu tinha sete anos. Isso tudo aqui não tinha luz, era mato. Foi um susto que eu levei, quando cheguei e abri a janela:
- Meu Deus do céu, minha irmã, aqui só tem chiqueiro de porco e galinheiro!

Ela disse:

- Aquilo não é porco não. É gente! (SEGALA E SILVA p.164) $)^{31}$

A violência que encontramos em alguns relatos do Varal é traço presente em diferentes momentos da literatura de Carolina. Eu classifico São Paulo assim: o Palácio é a sala de visita. A Prefeitura é a sala de jantar e a cidade é o jardim. E a favela é o quintal onde jogam os lixos (1976, p.30), vocifera compreensivelmente zangada a escritora no dia 15 de maio do também ano de 1958. Este trecho, que já apareceu no início da tese, é, no entanto, seguido de um delicado lirismo que desestabiliza o leitor desavisado e ávido por um discurso panfletário: [a] noite está tépida. O céu já está salpicado de estrelas. Eu que sou exótica gostaria de recortar um pedaço do céu para fazer um vestido. (1976, p. 30)

O lixo, dirá Zygmunt Bauman em Vidas Desperdiçadas (2005), [é] a parteira de toda criação - e seu mais formidável obstáculo. (p.32) Neste livro, parte integrante de sua vasta coleção, o sociólogo apresenta a noção de refugo humano, relacionada às diversas formas de vida humana excluídas dos processos produtivos da lógica do capital. E, em um pequeno trecho que recorto do todo porque me interessa para a reflexão aqui posta, se debruça sobre uma ${ }^{31}$ Depoimento de Neli Francisco de Farias, recolhido pelos autores do Varal de Lembranças em
06/11/1982. 
afirmação de Michelangelo que, ao ser perguntado sobre o processo de criação das suas esculturas, teria respondido tratar-se de um processo muito simples, bastando apenas escolher um bloco de mármore qualquer para dele cortar todos os pedaços supérfluos e fazer surgir suas obras. Para Bauman, ali, no auge do Renascimento, Michelangelo teria com essa afirmação traçado o guia da criação moderna:

\begin{abstract}
A separação e a destruição do refugo seriam o segredo comercial da criação moderna: cortando e jogando fora o supérfluo, o desnecessário e o inútil, seriam descobertos o belo, o harmonioso, o agradável e o gratificante. A visão de uma forma perfeita oculta num bloco informe de pedra bruta precede seu ato de nascença. $O$ refugo é o envoltório que esconde essa forma. Para desnudá-la, fazê-la emergir e ser, admirar sua harmonia e sua beleza sem mácula, deve-se primeiro desembrulhá-la. Para que algo seja criado, deve-se destinar alguma coisa ao lixo. O envoltório - o refugo do ato criativo - deve ser posto de lado, retalhado e removido para não atulhar o chão e restringir os movimentos do escultor. Não pode haver oficina artística sem uma pilha de lixo.
\end{abstract}

Isso, porém, torna o lixo um ingrediente indispensável do processo criativo. Mais ainda: confere ao lixo um poder aterrorizante, verdadeiramente mágico, equivalente ao da "pedra filosofal" do alquimista - o poder de realizar a maravilhosa transmutação da matéria inferior, sem significação e desprezível num objeto nobre, belo e precioso. Também faz do lixo a encarnação da ambivalência. O lixo é ao mesmo tempo divino e satânico. É a parteira de toda criação - e seu mais formidável obstáculo. O lixo é sublime: uma mistura singular de atração e repulsa que produz um composto, também singular, de terror e medo. (p.32)

A ambivalência grifada por Bauman é traço potente do Varal e da literatura de Carolina de Jesus, que com desenvoltura abandona o tom de denúncia para dar corpo a uma obra de intensidade poética permeada por passagens de humor ácido e sagaz que criam, em suas obras, as linhas de fuga que a libertam da clausura de um espaço narrativo de importância apenas sociológica para dar corpo e voz a movimentos de valor artístico. 
12 de dezembro... A Divina, filha da D. Maria minha empregada pediu-me 100 cruzeiros emprestado. (...) A D. Maria trabalha para mim. Quando chega visitas ela fica descontente e triste, murmurando:

- Meu Deus do céu, isto é o fim do mundo! Deus está me castigando. O mundo está virando. Eu, branca, ter uma patroa preta...

Eu dava risada e pensava: nós os pretos não revoltamos de ter patrões brancos. (...) Não sou exigente com as minhas empregadas. Não faço questão de côr. Gosto de D. Maria porque ela lava roupa muito bem. (JESUS, 1961, p.103)

Aqui, apresento este trecho de Casa de alvenaria ao lado da noção tão peculiar de lixo recortada de Bauman para evidenciar o contraste: enquanto o sociólogo, a partir da fala de Michelangelo, trata dos resíduos inúteis e chocantes na clave do "sublime", o que aterroriza, mas pode produzir o êxtase, Carolina faz um comentário ácido de humor para criticar o preconceito enraizado na sociedade.

Trata-se, portanto, de perspectivas diferentes que mais uma vez sublinham a potência da escritora no trato artístico com a palavra. Embora em Carolina a "transmutação" da raiva e da indignação em humor equivalha, guardadas as devidas proporções, ao raciocínio do sociólogo que parte de um exemplo da escultura clássica para tecer sua conhecida crítica àquilo que chama de modernidade líquida, com sua característica tendência ao descarte constante das coisas e das pessoas, faz-se interessante destacar a potência da escritora para operar essa espécie de "alquimia", lidando não só com o lixo material, mas com outras sujeiras da sociedade, como a rejeição racial e a opressão econômica.

Se o conceito canônico de arte implica em purificação, em livrar-se do lixo para então ver surgir obras belas e harmônicas, me interessa nesta pesquisa destacar outro prisma de observação mais próximo das noções apresentadas por Nancy - a de excrita - e por Calvino em sua Poubelle agréée. Para ambos, a própria 
arte, enquanto o que se expõe, excreta do corpo do artista, tem afinidade com o lixo, donde podemos extrair, talvez, sua qualidade sublime. A citação de Carolina, portanto, vem fazer a volta, mostrando melhor - a maneira das manchas na pele expostas por Varda - que a ambiguidade da obra construída pela economia (sublime?) da arte não implica, propriamente, em limpeza, purificação, mas em tirar efeitos críticos impactantes daquilo que a sociedade costuma dissimular, rejeitar e esconder.

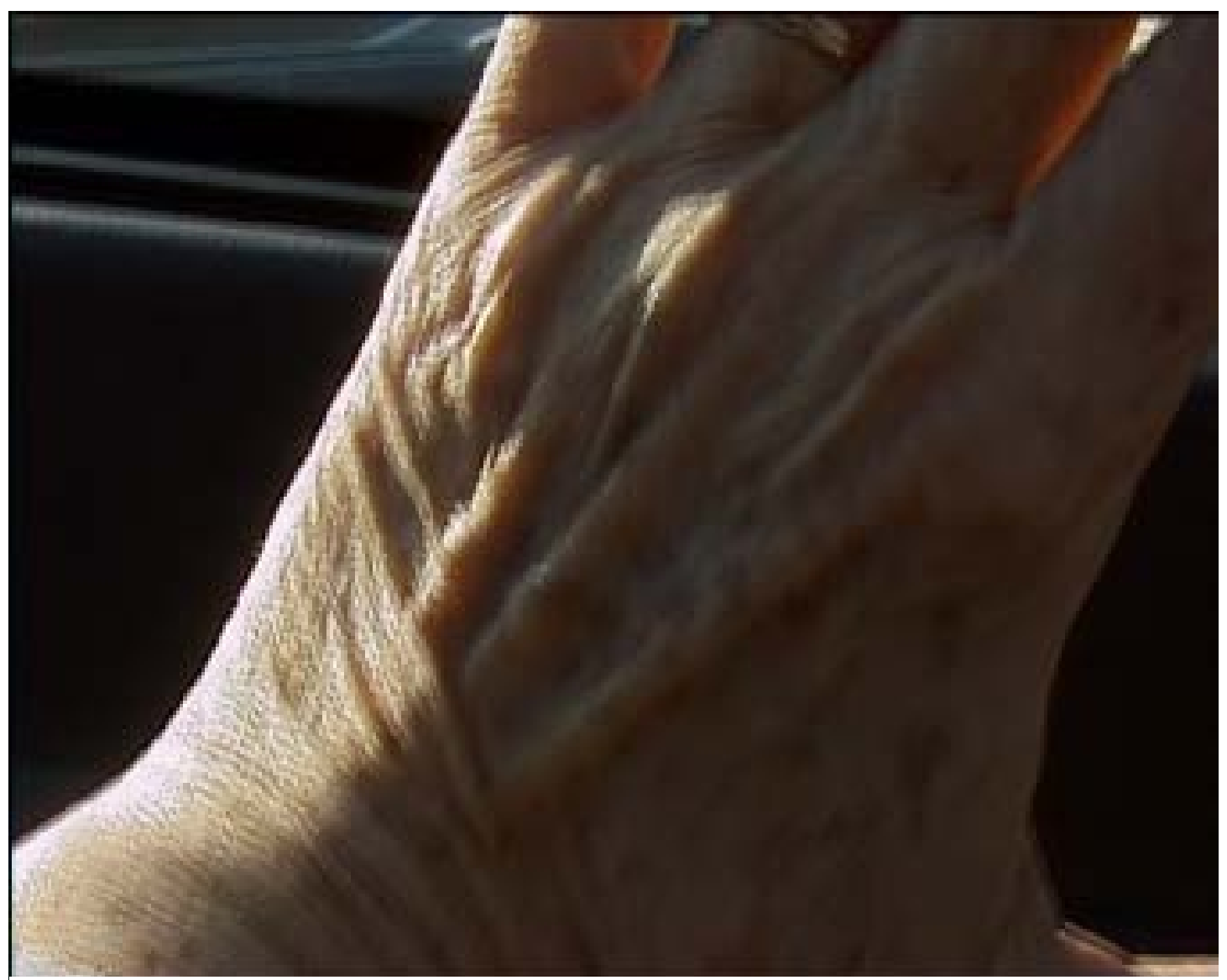

Figura 6: Frame de Os catadores e eu (Agnès Varda, 2000) 
23.

\section{Outras histórias}

Em artigo $^{32}$ recentemente publicado, o pesquisador Losandro Antonio Tedeschi promove um exercício de deslocamento conceitual pelo qual opera a noção de 'história menor' como dispositivo para pensar a história das mulheres. Partindo de uma reflexão sobre o espaço que a história oficial (maior), construída a partir da memória e das histórias do patriarcado, teria destinado às mulheres, 0 pesquisador vai olhar para a cozinha, o quarto, os cantos, as cartas, os bordados, as frestas e as notas de rodapé como lugares de arquivamento do feminino.

Em sua argumentação, a história oficial descartou o acontecimento histórico que envolvia o feminino justamente por estar diretamente relacionado às coisas consideradas menores, aquelas da ordem dos afetos, do privado e do subjetivo, operando por longo tempo um movimento ainda amplamente problemático, que contribui tanto para a clausura das mulheres e sua consequente invisibilidade nas narrativas oficiais, quanto para a dupla cilada de rotular toda a gama de mulheres como dotadas das mesmas características (e, ainda, de esvaziar toda a potência existente naquilo que é da ordem dos afetos).

A proposição de uma 'história menor' se dá em diálogo com as ideias apresentadas por Deleuze e Guattari no livro Kafka: por uma literatura menor (1977), no qual os filósofos se debruçam sobre a obra do autor e trazem para nosso campo de análise o adjetivo-conceito 'literatura menor' que, distanciandose da ideia de uma arte literária de baixo valor estético ou escrita em uma língua menor, abarca três importantes aspectos. O primeiro deles é o componente de "desterritorialização", pelo qual se abandona o território conhecido e opera-se a linha de fuga, em uma movimentação que nos coloca diante do segundo aspecto, aquele em que tudo é político. A afirmação do caráter político de toda literatura menor, por sua vez, está também intimamente relacionada ao terceiro aspecto elencado pelos filósofos, que trata da noção de que, nela, tudo é coletivo.

32 Por uma história menor - uma análise deleuziana sobre a história das mulheres (TEDESCHI, 2018) 
Virginia Woolf, em seu conhecido Um teto todo seu (1985), já apontava o espaço privado do quarto e das quatro paredes de casa como espaço constitutivo de identidades, resistências e desilusões, destacando o fato de que a produção e circulação da palavra escrita, de domínio sobretudo dos homens letrados e de alta posição social, implicou o uso abusivo do poder simbólico de narrar, relatar e significar, com pretensa superioridade, determinados momentos da realidade ligados diretamente aos triunfos e aos grandes feitos heroicos. (TEDESCHI, 2008, p.3)

Neste trabalho, o olhar para o catar se deu como resposta e aposta em um gesto tipicamente feminino para reger o movimento de pesquisa. Aqui, a sensibilidade aberta para a produção de mulheres, ou para criações artísticas que apostam no feminino como aquilo que caminha à margem, busca enfatizar certas brechas abertas nos discursos oficiais e grandes sistemas da humanidade. Não à toa, o olhar para histórias menores é nesta escrita provocativamente encenado em sua dimensão feminina, familiar, afetiva e maternal. Aquela que, desde sempre negligenciada pela história oficial, é também comumente afastada das produções acadêmicas. 
24.

\title{
O começo do mundo
}

\begin{abstract}
"No princípio o mundo não existia. As trevas cobriam tudo. Quando não havia nada, brotou uma mulher de si mesma. Surgiu suspensa sobre seus bancos mágicos e cobriu-se de enfeites que se transformaram em uma morada. Chama-se etãn bë tali bu (quatrzo, compartimento ou camada). Ela própria se chamava Yebá bëló (terra, tataravó), ou seja, avó do universo.". (KUMU e KENHíRI, 1980, p.51)
\end{abstract}

Um feto fêmea nasce com todos os óvulos que ela terá ao longo de sua vida. Uma mãe grávida produz dentro do útero o feto e seus ovários. Destes ovários surgirão os dois milhões de óvulos que uma mulher terá até a sua menopausa. Isso significa dizer, em outras palavras, que a sua avó te carregou dentro do ventre dela quando você era um óvulo microscópico no ovário da sua mãe. Vocês três estão emboladas há muito tempo, mas tem um momento em que se pula a geração do meio.

É que só a neta e a avó se abaixam e olham para o chão. Na infância, o chão é teto, afeto: das minhocâncias surgem o engatinhar, dos tombos os primeiros passos. Quando o corpo começa a cansar ele se volta de novo para baixo. Memória tem a ver com vida e morte. Nascimento e velhice. Benjamin vai dizer, lá n'O narrador: Considerações sobre a obra de Nikolai Leskov (1987), que é justamente no momento da morte que o saber e a sabedoria podem, a partir da autoridade que é conferida neste momento, serem finalmente transmitidos. Trabalhar com memória é estar de algum modo intrigado com a morte, é buscar uma forma de sobreviver mesmo em face aos grãos de areia que correm na ampulheta do tempo, escrevi em outro fragmento essa ideia que aqui retorna justamente porque essa escrita tem a ver com isso.

Um mito indígena da tribo Desâna nos explica o surgimento do mundo a partir da avó. Antes, quando não havia nada, [a]conteceram coisas misteriosas para que ela pudesse criar-se a si própria, inaugurando assim o universo. Esta é também uma tese sobre a passagem do tempo, a passagem do tempo como 
experiência transmitida pelo corpo de algumas mulheres ${ }^{33}$. Somos o que recolhemos e guardamos ou o que jogamos fora? O nascimento é um jogar fora aquele corpo estranho que por pouco mais de 40 semanas morou dentro de mim? Faço força e te expulso daqui. Do lado de fora você é sangue e sebo, promessa de vida. Rapidamente te limpam e sem o vérnix você agora é fome, mijo e merda. Expulso leite das minhas tetas, você suga, me suga, machuca e suga mais. Já não existo se não aos trapos, pedaço de carne a se desfazer para contar uma vida nova.

(O início e o fim de nossas vidas têm semelhança, são momentos-passagens em que contamos com terceiros para sobreviver à fragilidade das travessias ${ }^{34}$. A infância e a velhice são também momentos que colocam o sujeito em um espaço outro, deslocado da vida produtiva do trabalho. Há crianças e idosos muito idosos que mesmo sem querer trabalham, é verdade. Mas isso está fora do contrato social, ao menos teoricamente, até na lógica do capital. Ou deveria estar. Ou estava, que com esse governo fascista que hoje temos está sendo operado a toque de caixa o desmonte de todos os nossos direitos. $E$ isso que poderia ser um desabafo à parte da tese se mistura com ela: como pensar a vida ou fazer qualquer outra coisa atualmente sem ficar extremamente preocupada com a pulsão de morte que governa o Rio de Janeiro e o Brasil em junho de 2019?)

\footnotetext{
${ }^{33}$ Ser mulher, esse ser meio fora da ordem, que se inscreve pela falta. Virar a fragilidade ao avesso: se eu sou a falta, não tenho tanto a perder. Faço dessa semiescuridão minha força. Não quero escrever que nem homem, vou é dar à luz a uma tese bem mulherzinha.

${ }^{34}$ Este trecho e os apontamentos sobre nascimento e velhice que se desenrolarão a seguir partiram de ideias catadas na dissertação Comprida história que não acaba mais: do tecer ao texto e vice-versa (CARVALHO, 2014).
} 
25.

\section{A morte da avó}

No dia da morte da minha avó fomos todas encontrá-la. Ela morreu em casa, de madrugada, ao acordar de um sono leve e perguntar para a minha mãe, que naquela noite estava com ela, se estava com fome. Despertou, cuidou da filha e caiu morta. De uma hora para a outra o que quer que seja o fio da vida se desfez e colocou entre a gente uma distância abissal. Quando cheguei em sua casa ela estava deitada na cama ainda de camisola. Passamos o resto da madrugada e o começo da manhã ao seu lado. É impressionante como pesa um corpo morto. Carrega todo o peso do mundo? As nossas dores? Não deveríamos ficar mais leves?

A indústria da morte é implacável. Então minha avó morre dentro de sua casa e em pouco tempo chega até a gente uma lista de procedimentos. Tem que vir um bombeiro atestar a morte, tem que comprar um lugar para seu enterro (como são caros!), tem que chamar a funerária para cuidar do corpo morto, tem que velar, tem que levar para o cemitério.

Mas acontece que Dona Maria era uma mulher evangélica. E antes de ser enterrada ela passaria a noite sendo velada não no cemitério, mas na igreja que frequentava em Vila Isabel. Era a vontade dela, era a vontade das filhas. Nós, netas, como sempre, acolhemos. Concordar sempre foi a única resposta possível para a terceira geração de um silêncio inaugural. Okay, teríamos, então, mais um tempo com ela. Fomos ao desafio inicial: vestir minha avó. Ela já havia separado a roupa do culto de domingo, problema resolvido. E por acaso nos preparamos, três netas, uma de cada filha, para o ritual. Limpar o corpo morto com um pano molhado, vestir o corpo rígido com um vestido bonito e disfarçar o corpo pálido com algum tanto de maquiagem. Ser neta traz uma certa leveza para a relação. Em uma ordem natural das coisas minha vó sempre morreria e, na divisão familiar do trabalho e das neuroses, minha vida nunca dependeu da dela. Então, entre algumas tristezas e lágrimas, surgiam também sorrisos tímidos, lembranças carinhosas e a sensação de que ela estava sendo preparada para um baile de despedida. Foi o que aconteceu. O velório foi um 
misto de luto e festa. Eu antes não pensava dessas duas coisas andarem juntas, mas quando aconteceu, foi assim. As filhas estavam mergulhadas em uma tristeza desoladora que era difícil de ver, mas do lado de cá eu pensava que minha avó, se pudesse ver o que acontecia, iria embora daquele jeito, sabe? Triste-contente ${ }^{35}$.

35 Triste-contente é o modo como se encontrava Miguilim, conhecido personagem roseano de Campo Geral, quando, na partida de seu irmão Dito, viu amontoar-se um tanto de gente para dele se despedir:

"Desdormido, estonteado, desinteirado de si, no costume que começava a ter de ter, de sofrer, Miguilim sempre ficava em todo caso triste-contente, de que tanta gente ali estivesse, todos por causa do Dito, para honrar o Dito (...)". (ROSA, 1984, p. 110) 
26.

\title{
Percurso, ou notas sobre o processo de pesquisa
}

O poeta é como o trapeiro, apontou Benjamin a partir de Baudelaire. Aquele que, em suas andanças pela cidade, recolhe os restos perdidos, desprezados ou jogados fora pela sociedade. Colecionador de objetos que não são apenas antigos (colecionador de trapos, na tradução literal do alemão), mas que são descartados como inúteis, distantes de sua funcionalidade no tempo e no espaço, o trapeiro, como o emblemático flâneur, se opõe à alta velocidade da metrópole:

\begin{abstract}
Os poetas encontram o lixo da sociedade nas ruas e no próprio lixo o seu assunto heroico. Com isso, no tipo ilustre do poeta aparece a cópia de um tipo vulgar. Trespassam-no os traços do trapeiro que ocupou a Baudelaire tão assiduamente. Um ano antes de "O Vinho dos Trapeiros" apareceu uma descrição em prosa dessa figura: "Aqui temos um homem - ele tem de recolher na capital o lixo do dia que passou. Tudo o que a cidade grande jogou fora, tudo o que ela perdeu, tudo o que desprezou, tudo o que destruiu, é reunido e registrado por ele. Compila os anais da devassidão, o cafarnaum da escória; separa as coisas, faz uma seleção inteligente; procede como um avarento com seu tesouro e se detém no entulho que, entre as maxilas da deusa indústria, vai adotar a forma de objetos úteis ou agradáveis". Essa descrição é apenas uma dilatada metáfora do comportamento do poeta segundo o sentimento de Baudelaire. Trapeiro ou poeta, a escória diz respeito a ambos; solitários, ambos realizam seu negócio nas horas em que os burgueses se entregam ao sono; o próprio gesto é o mesmo em ambos. Nadar fala do andar abrupto de Baudelaire; é o passo do poeta que erra pela cidade à cata de rimas; deve ser também o passo do trapeiro que, a todo instante, se detém no caminho para recolher o lixo em que tropeça. (BENJAMIN, 1989, p. 78-79)
\end{abstract}

A aproximação da figura do trapeiro à do poeta é exercício antigo, tecido desde Baudelaire e grifado por Benjamin em suas leituras dos tipos originados no auge do capitalismo. Junto às prostitutas, às lésbicas e ao flâneur, dentre outros, o personagem aparece na obra benjaminiana como um dos heróis da resistência à consolidação do capitalismo. Ele é, grosso modo, uma imagem construída na 
poética de Baudelaire como figura que, incluída no grupo designado por Karl Marx como lumpemproletariado ${ }^{36}$, desvia-se do trabalho burocrático e produtivo que sustenta a vida burguesa e resiste à modernidade através da embriaguez do vinho, da revolta e de um emprego particular do tempo, contrário à velocidade da produção e do consumo de mercadorias, que a ocupação de viver a recolher o lixo produzido pela industrialização proporciona. Representando o que Benjamin vai chamar de uma espécie de indústria caseira situada na rua (1989, p. 16), os trapeiros chamavam atenção até mesmo daqueles que com eles compartilhavam os espaços das tabernas, gerando em todos questionamentos sobre até que ponto a modernidade conduziria o homem ao limite da miséria humana:

\begin{abstract}
Naturalmente, o trapeiro não pode ser incluído na boêmia. Mas, desde o literato até o conspirador profissional, cada um que pertencesse à boêmia podia reencontrar no trapeiro um pedaço de si mesmo. Cada um deles se encontrava, num protesto mais ou menos surdo contra a sociedade, diante de um amanhã mais ou menos precário. Em boa hora podia simpatizar com aqueles que abalavam os alicerces dessa sociedade. O trapeiro não está sozinho no seu sonho. Acompanham-no camaradas; também à sua volta há o cheiro de barris, e ele também encaneceu em batalhas. O bigode the pende como uma bandeira velha. Em sua ronda, vêmIhe ao encontro os mouchards, os agentes secretos sobre quem os sonhos Ihe dão supremacia. (BENJAMIN, 1989, p. 17)
\end{abstract}

Sobre seu surgimento na cena urbana, Benjamin destaca que um maior número de trapeiros surgiu nas cidades desde que, graças aos novos métodos

\footnotetext{
${ }^{36}$ Lumpemproletariado é um conceito apresentado por Marx que em tradução livre para o português significa "proletário trapo". Apresentado de modo pejorativo por Marx, o lumpemproletariado era formado por tipos como andarilhos, trapeiros e vagabundos, dentre outros, que, pela radicalidade de sua existência à margem, constituíam um grupo incapaz de tomar partido em função da classe trabalhadora e representavam um dano às intenções socialistas. Em uma leitura diferente, Benjamin, que associa Baudelaire à imagem do lumpemproletariado, avalia as potencialidades do lumpen enquanto desvio diante da monotonia do trabalho produtivo e burocrático que sustenta a vida burguesa racionalmente organizada em torno da atividade lucrativa. Para mais informações sobre as diferentes leituras de Marx e Benjamin acerca do lumpemproletariado, ver 'A revolução vagabunda: Baudelaire, Walter Benjamin e o fim da história'. (RAMIREZ, 2010)
} 
industriais, os rejeitos ganharam certo valor (1989, p. 16). Ou seja, o trapeiro traz consigo a contradição de, ao mesmo tempo em que se faz herói, por marcar uma resistência frente à efemeridade do tempo moderno, ser ele mesmo produto da modernização e da produção em massa das mercadorias, uma vez que é justamente esse excedente, característico da produção capitalista, que traz para a cena da metrópole o acúmulo de dejetos ${ }^{37}$.

Há, em Baudelaire, um gosto pela contradição que sustenta o paralelo entre a figura do trapeiro e a do poeta. Ele se reconhece neles. Estariam, ambos, resistindo à modernidade ao percorrer a cidade em busca daquilo que os outros rejeitaram. A lógica do capital, sabemos, atuou não somente sobre as coisas, mas também sobre as palavras. E, frente a mercantilização das Letras que tanto incomodou o poeta, a escolha temática por assuntos até então descartados da lírica tradicional se apresenta como um gesto subversivo. Daí então que, ao lado do trapeiro, desenha em sua obra um interesse combativo pelos restos e rastros, por tudo aquilo que escapa à lógica da utilidade, sobrevivendo como ruína na nova sociedade parisiense.

Nela o poeta cata imagens ordinárias da vida na metrópole e lhes oferece outros espaços. Nessa catação, caminha anônimo pela cidade em meio à multidão, recolhendo rimas e reproduzindo o gesto cambaleante do trapeiro. Ambos se debruçam sobre os cacos das coisas, naqueles locais onde se encontram os rejeitos, indivíduos e temas descartados pela sociedade e pela tradição literária:

Muitas vezes, à luz de um lampião sonolento,

Do qual a chama e o vidro estalam sob o vento,

Num antigo arrebalde, informe labirinto,

Onde fervilha o povo anônimo e indistinto,

Vê-se um trapeiro cambaleante, a fronte inquieta,

Rente às paredes a esgueirar-se como um poeta,

\footnotetext{
${ }^{37}$ Contradição da própria ordem capitalista, que de tudo se apropria. O trapeiro está à margem da margem, não se encaixando nem no grupo dos conspiradores (profissionais e amadores) que compunha a boêmia. Mas, com sua atividade, ao mesmo tempo contribui para a manutenção da ordem, servindo irremediavelmente ao deus Capital.
} 
E, alheio aos guardas e alcaguetes mais abjetos,

Abrir seu coração em gloriosos projetos.

Juramentos profere e dita leis sublimes,

Derruba os maus, perdoa as vítimas dos crimes,

E sob o azul do céu, como um dossel suspenso,

Embriaga-se na luz de seu talento imenso."

(BAUDELAIRE, 2006, p. 351)

Como derivação da figura do trapeiro de outrora surgiu, nesta pesquisa, a do catador. Recolhedor de lixo das grandes metrópoles contemporâneas, sua atividade também se baseia na tríade observar-escolher-recolher aquilo que está entre as sobras da sociedade. Essa atividade, que com o passar do tempo recebeu novos nomes, foi aqui convocada como motivo para pensar não apenas o trabalho de poetas/artistas/escritores, tal qual proposto por Benjamim, como também minha atividade de pesquisadora.

Pesquisar é atividade que exige uma constante observação reflexiva das coisas do mundo. É tarefa aqui entendida como próxima ao passo das catadoras que me acompanharam, donas de um caminhar interrompido a todo momento pelo gesto de olhar para baixo e recolher aquilo em que tropeçam. Matéria recolhida em um andar lento e cadenciado pelo desejo paradoxal de não deixar estes restos se perderem ao mesmo tempo em que se aproxima do movimento de jogá-los fora.

Um pensar debruçado, sugeriu Didi-Huberman (2015), em seu livro que recebe esse nome e ensaia uma diferenciação entre os modos de ver da vista sobrepujante e da vista abrangente, atribuindo ao gesto de se debruçar a qualidade de uma postura corporal engajada. O lá embaixo refere-se ao meu aqui, provoca o autor em seu texto, convocando-nos a pensar a distância entre dois pontos como um aspecto marcadamente relacional que sublinha um imperativo ético, estético e político na estatura do olhar: 
gesto de se debruçar, de se aproximar. A vista sobrepujante fixa o mundo e objetiva-o em coordenadas mensuráveis, explicitáveis (geográficas ou geométricas, por exemplo), que transformam o objeto visto em algo de «bem visto»; ainda que, para isso, ela deva manter as coisas à distância de acordo com uma distância estável ou, pelo menos, previsível nas suas variações (o que os pilotos dos aviões bombardeiros devem controlar, por exemplo). A vista abrangente, ao contrário, submete-se a um mundo em movimento e subjetiva-se em experiências interiores, pelo que deve abrir-se aos imprevistos de uma distância friável (que experimentam, imagino, aqueles que, entregues aos quatro ventos, praticam aquilo a que chamamos o "voo livre", parapente ou asa delta). (DIDIHUBERMAN, 2015, locais do Kindle 209-212 e 207-209)

O pensamento debruçado parte, com Didi-Huberman, da tentativa de trazer nossas experiências sensíveis para o campo teórico. Pensar o trabalho do pesquisador a partir do gesto de catar, teve, então, a ver com isso, com a proposta de entender a pesquisa como atividade corpóreo-intelectual implicada que exige uma atenção sensível do pesquisador. $\mathrm{Na}$ envergadura do olhar do pesquisador está também posta a sua tomada de posição política. Se, enquanto poeta, Baudelaire se compara ao trapeiro - simpatizante daqueles que abalam os alicerces da sociedade (Benjamin, 1989, p.17), enquanto pensador, Benjamin incorpora a força crítico-revolucionária dos dois, à medida que estuda suas atividades atento aos rastros deixados na Paris em crise de modernização.

Debruçar-se para tocar objetos abre espaço para que sejamos também tocados por eles e, aqui, o lixo em que o trapeiro tropeça é convocado para pensar também no resto que nele bate de volta. Nesse sentido, seu caminhar cambaleante é movimento reproduzido no corpo (corpus) de uma pesquisa que buscou acionar certa visão abrangente, consciente da potência que existe na precariedade de um olhar que abraça o não-saber prévio como modo de ver o mundo das coisas.

Esta é uma pesquisa que começou a ser construída com os restos de trabalhos anteriores, diga-se de passagem. Estive antes do doutorado envolvida em atividades acadêmicas que buscaram analisar criticamente a valorização e a 
construção midiática da figura pública do escritor no mundo contemporâneo, relacionando o conceito de autoria com o de performance e discutindo aspectos sobre como esse movimento incide na produção e circulação de suas obras, sobretudo na massiva construção de narrativas brasileiras que contam histórias de personagens-escritores em suas tramas (e também no caminho inverso, da construção de figuras públicas que se apresentam como escritores-personagens fora das páginas dos livros).

Tendo realizado investigações nessa área desde o curso de especialização que fiz na Universidade do Estado do Rio de Janeiro antes de migrar para a PUCRio, a minha proposta no início do doutorado era expandir essa pesquisa para o cenário latino-americano, buscando comparar as estratégias utilizadas por escritores em diferentes países. No primeiro ano do doutorado, no entanto, algumas questões começaram a me causar ruído. Isso porque, embora os caminhos de minha pesquisa tenham sempre se direcionado para uma análise crítica do fenômeno da proliferação literária das "escritas de si" como sintoma não apenas de uma sociedade pautada na espetacularização do eu, mas também como artifício de contestação da própria noção de sujeito, alguma coisa apontava para fora da circunscrição do nome próprio que, mesmo rasurado e forjado, insistia em aparecer.

E, nos encontros e desencontros com o corpus daquela outra pesquisa, comecei a me questionar: "o que resta de uma literatura que insistentemente fala de si?". Passado algum tempo, o que ficou dessa pergunta foram palavras. Isso porque, mais do que pensar sobre a literatura que insistentemente fala de si, me vi envolvida com a ideia do que resta, do que sobra, e sobretudo do que restou abandonado nas minhas pesquisas anteriores. Nesse sentido, o resto adquiriu o estatuto de resistência das ideias e interesses que me atravessaram, tanto no âmbito dos estudos acadêmicos, quanto da vida profissional construída fora da universidade.

Foi então que, a partir do movimento de olhar para trás, de operar um desvio, me vi catando na memória encontros que insistiam em permanecer no meu campo de interesse. Foram, de forma geral, encontros com obras e teorias que 
giram em torno de uma noção de resto e de outras palavras que dela derivam, semântica, morfológica e sonoramente: se por um lado resto, resíduo, lixo, excremento, ruína e fragmento são exemplos de signos que aparecem como noções-artifício para a criação de estratégias de sobrevivência da experiência no contemporâneo; olhar, observar, demorar, recolher, respigar, colecionar e resistir são gestos de um certo modo de viver uma pesquisa.

Operar um desvio, aqui, segue a provocação benjaminiana método é desvio, apresentada no prefácio da Origem do drama barroco alemão (1984) e belamente traduzida para nosso tempo por Jeanne Marie Gagnebin no texto intitulado "Algumas teses impertinentes sobre o que não fazer num curso de Filosofia" (2006). Nele, Gagnebin elenca quatro regras para o ensino de filosofia, convocando docentes a não temer a errância e a abraçar a necessidade dos desvios, com sua temporalidade marcada por um fluxo de pensamento que para, volta para trás, vem de novo, espera, hesita, toma fôlego, [sendo] o exato contrário de uma consciência segura de si mesma, de seu alvo e do itinerário a seguir (GAGNEBIN, 2013, p.146). O convite é, sobretudo, para que aprendam e ensinem a arte da paciência, resistindo ao produtivismo acadêmico-tecnicista

\footnotetext{
contra a pressa, a produtividade, a concorrência, a previsibilidade, a especialização custe o que custar, as certezas e as imposições. Podemos exercer, treinar, mesmo numa sala de aula, sim, pequenas táticas de solapamento, exercícios de invenção séria e alegre, exercícios de paciência, de lentidão, de gratuidade, de atenção, de angústia assumida, de dúvida, enfim, exercícios de solidariedade e de resistência. (GAGNEBIN, 2006)
}

O método desviante se propõe, portanto, como um outro tempo e modo de se relacionar com o saber. E pensar o método de escrita desta pesquisa foi desde sempre uma questão primordial, de posicionamento mesmo. Qual espaço vou ocupar para conversar com esse objeto que recolhi? Me perguntei diversas vezes durante o processo. Ou, diante da proposta de me encontrar com criações artísticas que, em lugar de apenas narrar os restos materiais e simbólicos da sociedade, fossem construídas com e a partir deles, me vi diversas vezes paralisada na posição de quem de si suspeita. Como fazer esse questionamento 
sobre as formas de narrar ecoar na minha escrita? Como escrever e falar com pedaços e destroços ${ }^{38}$ ?

${ }^{38}$ Escrever e falar com pedaços e destroços é trecho do ensaio 'Manchas na pele, linguagem' de Nuno Ramos:

Fico imaginando o que teria acontecido se tivessem desafiado o cataclismo e construído uma linguagem com os restos da antiga, calcinada. Se ao invés de tornarem-se ventríloquos das coisas, tivessem transformado as próprias cinzas, a terra deserta, o mau cheiro de tantos bichos mortos, expostos ao céu e à risada das hienas, se tivessem transformado as próprias hienas em sujeito e predicado de seu mundo moribundo. Se tivessem a coragem de escrever e falar com pedaços e destroços. Então seriam parte desse caos, desta correnteza de lava e de morte, mas trariam a cabeça erguida, seus passos teriam o tremor do terremoto que os aniquilou e sua risada a potência do vento lá fora. (RAMOS, 2008, p.30-31) 
27.

\section{A escrita fragmentária}

Amigos, o solo é pobre. Precisamos de lançar muitas sementes para obter uma modesta colheita, propôs Novalis na epígrafe de um de seus mais emblemáticos conjuntos de fragmentos, intitulado Pólen. O texto, representativo da primeira geração dos românticos alemães, foi um marco na teoria literária moderna. Nele, Novalis inaugurou uma potente aproximação entre o fazer teórico e artístico, construindo em fragmentos uma crítica poética da poesia de seu tempo.

A proposição de Novalis para lançar muitas sementes atravessou de forma incontornável esta pesquisa. Ao decidir escrever uma tese como quem traça um mapa, operando uma colagem de fragmentos, estive implicada em algumas questões teórico-conceituais e outras de cunho prático. Se por um lado a adoção do fragmento como forma de escrita foi uma escolha consciente por um procedimento estético que assume a precariedade como sintoma de época e a tensão e o choque como estilo, por outro, é preciso grifar, a decisão se deu também pelo fato de eu ter sido tomada por um impulso insistente de começar novos textos sem que uma leitura exaustiva se colocasse nos anteriores.

Ao me decidir escrever sobre obras e teorias que giram em torno de uma noção ampla como a de resto, muitas foram as possibilidades abertas. Havia, antes de qualquer outra coisa, a necessidade de falar do resto como resistência, como aqueles atravessamentos inconclusos, que passam pela gente e não se encerram na coisa em si, retornando sempre, de diferentes formas, em outros momentos. Mas teve também o resto em seu sentido mais literal: lixo, dejeto. Além disso, outras ideias que giravam em torno dele, como a noção de vidas descartadas porque fora da lógica do consumo, a articulação entre lixo e memória, o projeto de olhar para histórias silenciadas, porque entendidas como lixo da história. E, ainda, o resto como tudo o que do corpo se extrai ou nele se inscreve, sua prole e seus excrementos, claro, mas também suas marcas e manchas, resto marcado na pele de uma vida que segue seu curso. 
Para dar conta dessa multiplicidade, comecei muito mais do que concluí. Foi preciso lançar muitas sementes, porque, como diz João Barrento, ao fim de seu ensaio "O que resta sem resto" (2010):

[o] leitor de fragmentos, leitor por excelência melancólico e de olhar alegórico, é, numa bela expressão, quase intraduzível, de Pascal Quignard, frappé d'origine (tocado pelo sopro das origens?). Como aquele que os escreve, sente-se atraído pelos começos, e tende a multiplicá-los adiando sine linea a conclusão. (BARRENTO, 2010, p.77)

Mas teve ainda algo a mais.

Durante a escrita, o valor conceitual das atividades do catador e do trapeiro, extraído das fontes teóricas e transformado em critério para a recolha dos objetos com os quais conversei, foi estendido à operação crítica da tese. E, nessa caminhada, a recolha, entre proposital e acidental (por obra do acaso), de noções teóricas e objetos artísticos, resultou em incentivo ao imaginário que desdobrou o trabalho crítico em exercícios inventivos de escrita onde texto e vida, embora precários e fragmentados, foram construindo-se pela justaposição das diferenças e contágio de um pelo outro.

Para dar conta desse movimento, lancei mão não apenas do fragmento, mas também do ensaio como forma em sua dupla dimensão de uma escrita que explora tanto o intelectivo (que inclui ou procura delinear conceitos e expõe sua percepção crítica e autocrítica) quanto o sensível (construindo-se com a linguagem sensorial da arte). A forma se impôs, portanto, como atividade de ensaiar, aqui apresentada como ação justamente para enfatizar uma pesquisa que, descrente dos modelos e conceitos unificadores e totalizantes, buscou compor um texto crítico com o movimento da vida. Isso porque, se agora com Adorno (2003) posso apostar na escrita ensaística como aquela que se constitui a partir de um não-saber, entendendo a verdade como algo que não só se situa além dos fatos, mas se dá no próprio movimento do pensamento, a partir dele posso também assumir o ensaio como texto que parte da experiência daquele 
que escreve ${ }^{39}$ e compõe-se experimentando, ouvindo, cheirando e tocando seu objeto: montando e desmontando-o nas suas múltiplas possibilidades.

${ }^{39}$ A experiência individual é aqui entendida como aquela que é inevitavelmente construída e mediada por uma experiência coletiva mais abrangente. Nas palavras de Adorno:

"A relação com a experiência - e o ensaio confere à experiência tanta substância quanto a teoria tradicional às meras categorias - é uma relação com toda a história; a experiência meramente individual que a consciência toma como ponto de partida por sua proximidade, é ela mesma mediada pela experiência mais abrangente da humanidade histórica. " (2003, p.26). 
28.

\section{Pobreza de experiência}

A escrita da tese foi também um eco: [s]omos 'pobres em experiência'? Façamos dessa mesma pobreza - dessa semiescuridão - uma experiência ${ }^{40}$. E o diálogo aqui se dá com a noção de declínio da experiência tal qual anunciado por Benjamin que, em seu texto "Experiência e Pobreza" (1987), introduz o assunto com a narração lendária de um conto antigo em que um pai, em seu leito de morte, fala para seus filhos da existência de um tesouro enterrado em seus vinhedos. Após ouvir o pai, os filhos cavam, cavam e cavam, mas não encontram nenhum sinal do tesouro. Ao final da colheita, no entanto, seus vinhedos produzem mais do que qualquer outro da região e é então que a prole assimila a experiência transmitida pelo pai, cujo ensinamento estava na proposição de que a felicidade não estaria na riqueza e sim no trabalho, ou, ainda mais significativo: encontrava-se justamente na experiência transmitida pelo pai quase-morto.

Essa narrativa abre no texto a reflexão sobre uma questão cara ao filósofo, a perda da capacidade de contar histórias e de, com elas, intercambiar experiências:

Sabia-se exatamente o significado da experiência: ela sempre fora comunicada aos jovens. De forma concisa, com a autoridade da velhice, em provérbios; de forma prolixa, com a sua loquacidade, em histórias; muitas vezes como narrativas de países longínquos, diante da lareira, contadas a pais e netos. Mas para onde foi tudo isso? Que foi feito de tudo isso? Quem encontra ainda pessoas que saibam contar histórias como elas devem ser contadas? Que moribundos dizem hoje palavras tão duráveis que possam ser transmitidas como um anel, de geração em geração? Quem é ajudado, hoje, por um provérbio oportuno? Quem tentará, sequer, lidar com a juventude invocando sua experiência? (BENJAMIN, 1987, p.114)

${ }^{40}$ DIDI-HUBERMAN, 2011, p. 127 
Falar do declínio da experiência a partir de Benjamin, requer debruçar-se sobre a proposição de que, para o filósofo, a noção de experiência parte daquilo que os mais velhos costumavam transmitir aos mais jovens. Esse ponto de partida nos coloca diante de uma dupla afirmação, que fala tanto da experiência como algo que se constitui ao longo do tempo, quanto do pressuposto de que a experiência é algo comunicável, transmissível. Constituir-se ao longo do tempo, por sua vez, significa ser de outra ordem que não a da imediaticidade. Ser comunicável, transmissível, implica um deslocamento espacial de um ponto ao outro e, dentro desta perspectiva, a experiência é algo que se dá por decantação, requer um processo de gestação e amadurecimento para que o vivido adquira significado, sedimente-se e possa, enfim, ser transmitido.

A demanda por tempo para sedimentação, aqui, é o dado que apresenta a figura do idoso como lugar de repositório da experiência. Os mais velhos são invariavelmente aqueles pelos quais o tempo passou e por isso são aqueles que, ao menos quantitativamente, muita coisa viveram. Para ser um sábio, ou seja, possuir uma sabedoria que possa ser transmitida, é necessário, no entanto, que aquele que dispôs de muito tempo tenha ao longo de sua vida extraído significado de suas vivências, transformando-as em experiência comunicável. E estamos aqui diante da discussão benjaminiana acerca da experiência enquanto Erfahrung e sua distinção da vivência (Erlebnis). Gagnebin vai mostrar, em "Não contar mais?" (2013), que a experiência entendida como Erfahrung significa, por seu radical 'farh', atravessar uma região durante uma viagem (p. 58), ligando-se, portanto, à transformação e à modificação possibilitadas pelo atravessar, enquanto a noção de Erlebnis se encontra vinculada a uma vivência individual que não se liga à comunidade.

A distinção entre o que se dá na esfera moderna individual(ista) daquilo que se dava de forma coletiva em outros tempos é importante porque, segundo Benjamin, para que a experiência se dê é preciso algo como uma tradição compartilhada, um universo de referências comum e estável que possibilite que as histórias sejam escutadas e seguidas. E, quando Benjamin fala da experiência como algo que é transmissível dentro de uma tradição compartilhada, o filósofo fala de algo que se dá em oposição ao tempo deslocado e entrecortado do 
trabalho no capitalismo moderno ou, em outras palavras, que se dá dentro de uma vida partilhada nas sociedades artesanais pré-capitalistas, pois somente lá o que se transmitia podia ser recepcionado por outros como algo significativo. Nesse sentido, no entanto, é importante destacar que:

\begin{abstract}
Benjamin liga indissociavelmente as mudanças da produção e da compreensão artísticas a profundas mutações da percepção (aisthêsis) coletiva e individual. A importância deste processo deve ser ressaltada, pois ele exclui, nas descrições de Benjamin, os argumentos moralizantes, tão frequentes em numerosas descrições contemporâneas, que nos chamam a voltar para uma continuidade perdida, a reencontrar um enraizamento secular. Por certo, Benjamin não escapa, às vezes, a um tom nostálgico, tom comum, aliás, à maioria dos teóricos do "desencantamento do mundo", quando evoca as "comunidades de outrora nas quais memória, palavra e práticas sociais eram compartilhadas por todos". Porém, sua visada teórica ultrapassa de longe esses acentos melancólicos. Ela se atem aos processos sociais, culturais e artísticos de fragmentação crescente e de secularização triunfante, não para tentar tirar dali uma tendência irreversível, mas, sim, possíveis instrumentos que uma política verdadeiramente "materialista" deveria poder reconhecer e aproveitar a favor da maioria dos excluídos da cultura, em vez de deixar a classe dominante se apoderar deles e deles fazer novos meios de dominação. (GAGNEBIN, 2013, p.55-56)
\end{abstract}

Fazendo resistência ao avanço da máquina capitalista, do desenfrear da informação e dos horrores das guerras, Benjamin se debruçou sobre as ruínas, as histórias não contadas, a infância do olhar. Sua filosofia, aponta também DidiHuberman, não confundia o declínio da narrativa com o seu fim. Sua mensagem não era a do desespero. Frente ao fascismo, suas ideias encontravam respiros na delicadeza que povoava seus escritos de arte e imagens poéticas. Havia ali o tempo todo uma proposição para que se organizasse o pessimismo ${ }^{41}$, pois,

${ }^{41}$ Dirá Didi-Huberman:

(...) Benjamin soube "organizar seu pessimismo" com a graça dos vaga-lumes, buscando, por exemplo, entre o teatro épico de Bertold Brecht e a deriva urbana dos poetas surrealistas, entre a Biblioteca Nacional e a Passage des panoramas, esse "espaço de imagens" 
mesmo em um mundo em que os inimigos não cessam nunca de vencer, são a esperança e os desejos que resistem que nos convidam à insurgência, resistindo em manter acesa a chama do espírito revolucionário:

\begin{abstract}
O valor da experiência caiu de cotação, é verdade. Mas cabe somente a nós não apostarmos nesse mercado. Cabe somente a nós compreendermos onde e como "esse movimento (...) ao mesmo tempo, tornou sensível uma nova beleza naquilo que desaparecia (...)." A "imagem dialética" à qual nos convida Benjamin consiste, antes, em fazer surgirem momentos inestimáveis que sobrevivem, que resistem a tal organização de valores, fazendo-a explodir em momentos de surpresa. Busquemos, então, as experiências que se transmitem ainda para além de todos os "espetáculos" comprados e vendidos à nossa volta (...). Somos "pobres em experiência"? Façamos dessa mesma pobreza - dessa semiescuridão - uma experiência. (DIDIHUBERMAN, 2011, p. 127)
\end{abstract}

A proposição de Didi-Huberman para que façamos dessa semiescuridão uma experiência é olhar que enxerga justamente no declínio da experiência sua possibilidade de sobrevivência. Em lugar da luz que tudo ofusca, do saber total que tudo domina, a potência da adoção do desconhecido como ação de resistência que não acata a informação ou a clareza excessiva dos discursos dominantes. O pensamento à altura da experiência: trapeiro, criança, mulher, vaga-lume. O que está em vias de desaparecimento, mas não se extingue, porque está sempre reaparecendo em outro lugar ${ }^{42}$ :

O não-saber, porém, não é escuridão total, não é completa ignorância, mas um saber discreto. É fiapo de saber que inquieta seu tempo. Obscurece o espetáculo, a luz dos projetores, conforme a definição de "contemporâneo" empreendida por Agamben. Nesse

capaz de contradizer a polícia - as terríveis restrições - de sua vida. O valor da experiência havia caído, mas Benjamin respondeu a isso com imagens de pensamento e com experiências de imagem cujos textos sobre o haxixe oferecem ainda, entre outros, alguns exemplos surpreendentes por suas ressurgências de "aura autêntica" ou de infância do olhar sobre todas as coisas. (2011, p.129)

${ }^{42}$ CORREIA, 2012, p.158 
sentido, sobreviver é, a partir do declínio da experiência, resistir ao excesso de luz e permanecer como resto. Nesse caso o tempo também aparece como resto; o contemporâneo torna-se uma trama intrincada de temporalidades esgarçadas, esfarrapadas. Temos, assim, a experiência como uma revelação provisória e em trapos. Vaga-lumes são imagens-restos, momentaneamente visíveis ou legíveis - imagens impuras (como o lixo), de focalização difícil. Contra o comportamento imposto pelo poder de consumo, sua resistência inscreve um espaço intermitente, nômade e um tempo estilhaçado. (CORREIA, 2012, p.158) 
29.

Por fim, organizar o pessimismo

As mulheres e as crianças são as primeiras que desistem de afundar navios.

(Ana C.)

As notícias de fora atravessam de novo essa escrita. Vazaram trechos de conversas comprometedoras entre um certo juiz e procuradores que têm relação direta com o resultado das últimas eleições. Há dois dias uma audiência pública na UERJ sobre a política de cotas terminou com deputados da direita agredindo estudantes negros. Um e-mail recebido pelo jornalista responsável pela reportagem que expõe trechos das tais conversas comprometedoras se vangloria e zomba da execução da vereadora eleita Marielle Franco em 2018. Organizar o pessimismo. Benjamin vai dizer também que, com o passar do tempo, o homem passou a ser privado do espetáculo da morte. Esta, com a modernidade, o avanço da burguesia e sua característica assepsia, teria passado a ser confinada, guardada, escondida.

(Teria sido no quarto de despejo?)

Penso de novo na execução da Marielle em praça pública. Também no golpe, dentre outras coisas, machista, que nos arrancou a primeira presidenta mulher do poder. Perco a força e fico confusa. Não estou dando conta. Nem do Brasil, nem dessa escrita. É que às vezes engato palavras, mas em outras me falta o ar.

Viro o meu texto de novo para o nascimento, pulsão de vida. Teria aqui acontecido o mesmo? Outrora ritual coletivo, saber partilhado entre mulheres, 0 nascimento foi também transferido para o branco macho do hospital. Morria-se muito ao nascer, é verdade, mas não seriam vida e morte matéria palpável do que somos feitos? Aliás, ao nascer, a criança ainda não está viva, é preciso que 
vingue $^{43}$. É preciso vingar. Se vingar? É isso que fazemos durante esse intervalo entre chegar aqui e ir embora?

Estou cada vez mais confusa e o tempo está acabando. Tic tac, acho que vou parar por aqui. É que eu queria escrever uma tese sobre coisas grandes, eu tinha uma porção de coisas grandes para conquistar, mas tem sempre você aqui pequena bagunçando tudo. Tem um pulmão que nasceu imaturo e trouxe para essa pesquisa o tempo fragmentado, entrecortado pelas doenças da infância. Que luta fazer de um corpo fortaleza para respirar a vida!

Máscara de oxigênio: essa escrita é pra você, meu amor.

${ }^{43}$ CARVALHO, 2014. 
30.

\section{Referências bibliográficas}

ADORNO, T. "O ensaio como forma". In: Notas de literatura I. São Paulo, Duas Cidades / Ed. 34, 2003

BAUDELAIRE, C. As Flores do Mal. Trad. Ivan Junqueira. Rio de Janeiro. Nova Fronteira, 2006.

BAUMAN, Zygmunt. Vidas Desperdiçadas. Rio de Janeiro: Jorge Zahar Ed., 2005.

BARRENTO, João. O gênero intranquilo - anatomia do ensaio e do fragmento. Lisboa: Assírio \& Alvim, 2010

BENJAMIN, Walter. Origem do drama barroco alemão. São Paulo: Brasiliense, 1984.

. Magia e técnica, arte e política: ensaios sobre literatura e história da cultural (Obras escolhidas I). São Paulo: Brasiliense, 1987.

. Charles Baudelaire: Um lírico no auge do Capitalismo (Obras escolhidas III). São Paulo: Brasiliense, 1989.

. Reflexões: a criança, o brinquedo, a educação. São Paulo: Duas Cidades; Editora 34, 2002:

. Passagens. Belo Horizonte: Editora UFMG, São Paulo: Imprensa oficial do Estado de São Paulo, 2009

Rua de Mão Única: Infância Berlinense: 1900. Edição e tradução de João Barrento. Belo Horizonte: Autêntica Editora, 2017.

CALVINO, Italo. La poubelle agréée. In: CALVINO, Italo. O caminho de San Giovanni. Trad. de Roberta Barni. São Paulo: Companhia das Letras, 2000.

CARVALHO, Cíntia de Sousa. A escuta de memórias nos labirintos da favela: reflexões metodológicas sobre uma pesquisa-intervenção. Tese (doutorado) Pontifícia Universidade Católica do Rio de Janeiro, Departamento de Psicologia, 2015.

CARVALHO, Marcela Fernandes de. Comprida História que não acaba mais: do tecer ao texto e vice-versa. Dissertação (mestrado). Pontifícia Universidade Católica do Rio de Janeiro, Departamento de Psicologia, 2014.

CESAR, Ana Cristina. A teus pés. In: Poética. São Paulo. Companhia das Letras, 2013. 
CHIARA, Ana Cristina de Rezende. Intelectuais Delirantes. In: XI Congresso Internacional da ABRALIC, 2008, São Paulo. Anais do XI Congresso Internacional da Associação Brasileira de Literatura Comparada, São Paulo: São Paulo: Abralic -e.books, 2008. . Ensaios de possessão(irrespiráveis). Rio de Janeiro: Caetés, 2006.

CORREIA, Maraíza Labanca. Sombria luz: o resto em Nuno Ramos. In: Revista Graphos, vol. 14, n² 1, 2012. UFPB/PPGL. ISSN 1516-1536

DELEUZE, Gilles. "Para dar um fim ao juízo". In: Crítica e Clínica. Tradução de Peter PálPelbart. Rio de Janeiro: Editora 34, 1997.

DELEUZE, Gilles; GUATTARI, Félix. Mil platôs. Capitalismo e esquizofrenia. Volume 1. São Paulo: Editora 34, 1995.

1977.

.Kafka: por uma literatura menor. Rio de Janeiro: Imago Editora,

DIDI-HUBERMAN, Georges. Pensar debruçado. Lisboa: KKYM, 2015.

- Atlas - como levar o mundo às costas. Disponível em:http://www.artecapital.net/perspetiva-119-atlas-como-levar-o-mundo\%C3\%A0s-costas--apresentacao-por-georges-didi-huberman.Último acesso: 5 jan. 2017

2011.

Sobrevivência dos vagalumes. Belo Horizonte: Editora UFMG,

EVARISTO, Conceição. 2007. "Da grafia-desenho de minha mãe, um dos lugares de nascimento de minha escrita". In: ALEXANDRE, Marcos Antônio Alexandre (org.) Representações performáticas brasileiras: teorias, práticas e suas interfaces. Belo Horizonte: Mazza, 2007.

FERNANDEZ, Raffaella Andréa. "Prólogos" para um Journal de Bitita/ Diário de Bitita ou Por que editar Carolina? In: SCRIPTA, Belo Horizonte, v. 18, n. 35, p. 285-292, $2^{\circ}$ sem. 2014.

FERRAZ, Bruna Fontes. Escritas fora do corpo: a literatura residual de Ítalo Calvino. In: Anu. Lit., Florianópolis, v. 20, n. Esp 1, p. 93-103, 2015. ISSNe 21757917

GAGNEBIN, Jeanne Marie. Lembrar Escrever Esquecer. São Paulo: Editora 34, 2006.

2013.

. História e Narração em Walter Benjamin. São Paulo: Perspectiva, 
O método desviante. Algumas teses impertinentes sobre o que não fazer num curso de filosofia, 2007. Disponível em: http://oficinadefilosofia.wordpress.com/2007/02/21/o-metodo-desviante-porjeanne-mariegagnebin/ .

GINZBURG, Jaime. Crítica em tempos de violência. Tese apresentada como requisito parcial para obtenção do título de livre docente em Literatura Brasileira na Faculdade de Filosofia, Letras e Ciências Humanas da Universidade de São Paulo. 2010.

JAFFE, Noemi. Livro dos começos. São Paulo: SESI-SP, 2018.

JESUS, Carolina Maria. Quarto de despejo. Rio de Janeiro: Francisco Alves, 1976. . Diário de Bitita. São Paulo: SESI-SP, 2014.

\section{1.}

. Casa de Alvenaria. Rio de Janeiro: Editora Paulo de Azevedo,

KUMU, Umúsin Pnalõn e KENHÍRI, Tolamãn. Antes o mundo não existia. $A$ mitologia heroica dos índios Desâna. São Paulo: Cultura Editora, 1980.

LAZZARETI, Angelene. E N T R E: a trama dos corpos e do acontecimento teatral. Tese (Doutorado) -- Universidade Federal do Rio Grande do Sul, Instituto de Artes, Programa de Pós-Graduação em Artes Cênicas, Porto Alegre, 2019.

NANCY, Jean-Luc. L'excrit. Rio de Janeiro: Alea: Estudos Neolatinos, no 15/2 p.312-320 julho-dezembro 2013.

PAIXÃO, Fernanda. Laboratório Madalena: derivações de uma experiência cênica. 2012. Monografia (Graduação) - Universidade Federal do Estado do Rio de Janeiro, Rio de Janeiro.

RAMIREZ, Paulo Niccoli. A Revolução Vagabunda: Baudelaire, Walter Benjamin e o fim da história. In: Ponto-e-Vírgula - revista do Programa de Estudos PósGraduados em Ciências Sociais da Pontifícia Universidade Católica de São Paulo (PUC-SP). n. $8.2^{\circ}$ semestre de 2010

RAMOS, Nuno. Ó. São Paulo: lluminuras, 2008.

ROLNIK, Suely. Os mapas movediços de Öyvind Fahstön. 2000.

ROSA, Guimarães. Primeiras Estórias. Rio de Janeiro: Nova Fronteira, 1988.

Fronteira, 1984.

Manuelzão e Miguilim (Corpo de baile). Rio de Janeiro: Nova 
SILVA, Francisco Thiago Camêlo da. Cartografias da infância. Dissertação (mestrado) - Pontifícia Universidade Católica do Rio de Janeiro, Departamento de Letras, 2017.

SEGALA, Lygia; SILVA, Tania Regina da (Orgs.). Varal de lembranças: histórias da Rocinha. Rio de Janeiro: União Pró-Melhoramentos dos Moradores da Rocinha; Tempo e presença; SEC/MEC/FNDE, 1983.

TEDESCHI, Losandro Antonio. Por uma história menor - uma análise deleuziana sobre a história das mulheres, in Revista Estudos Feministas. Vol.26. Florianópolis, 2018. Epub 15-Jan-2018.

WOOLF, Virginia. Um teto todo seu. Rio de Janeiro: Nova Fronteira, 1985

\section{Filmografia}

ESTAMIRA. Ficha técnica: Brasil, 2006. Direção: Marcos Prado. Produção: Marcos Prado e José Padilha. Colorido, 116 min.

LES GLANEURS et La glaneuse. Ficha técnica: França, 2000. Direção: Agnès Varda. Produção: Agnès Varda. Colorido, 82 min. 